\title{
THE SOUL AND THE BRAIN BETWEEN ANATOMY AND NATURPHILOSOPHIE IN THE EARLY NINETEENTH CENTURY
}

by

\author{
MICHAEL HAGNER *
}

In the years around 1800 two hypotheses led to fundamental discussions in German neuroanatomy and philosophy. The first was developed by Samuel Thomas Soemmerring (1755-1830) in his treatise Über das Organ der Seele (On the organ of the soul) of 1796, in which he postulated that the organ of the soul was located in the fluid of the cerebral ventricles. ${ }^{1}$ The second was published only two years later by Franz Joseph Gall (1758-1828) in a short and schematic paper, in which he developed a research programme based on the assumption that several independent organs or faculties of mind were located in the cerebral cortex. ${ }^{2}$ This was his doctrine of organology, later known as phrenology, although Gall himself never used this term.

In comparing the two, their differences are usually stressed more than their similarities. It has often been argued that Soemmerring's attempt was a late revival of the medieval cell doctrine, an opinion that, as I will show, is based on a profound misunderstanding of Soemmerring's intentions. ${ }^{3}$ Looking at the historical approaches

* Dr Michael Hagner, Institut für Geschichte der Medizin, Georg-August-Universität Göttingen, Humboldtallee 11, 3400 Göttingen, Germany.

A preliminary version of parts of this paper was presented to seminars at the Wellcome Institute for the History of Medicine and the Wellcome Unit in Manchester. I have benefited enormously from discussion after these lectures. Furthermore I am deeply indebted to Dr William F. Bynum, Prof. Dietrich von Engelhardt, Prof. Otto-Joachim Grüsser, Dr Christopher J. Lawrence, Peter N. Robinson, Dr Bettina Wahrig-Schmidt, and two anonymous referees for their comments and criticisms. A part of the research was supported by a grant from the Deutsche Forschungs-Gemeinschaft, while I was working at the Physiologisches Institut, Freie Universität Berlin, and at the Wellcome Institute. I am grateful to my colleagues and friends at the Institut für Medizin- und Wissenschaftsgeschichte, Medizinische Universität zu Lübeck, where I wrote this paper.

\footnotetext{
${ }^{1}$ Samuel Thomas Sömmerring, Über das Organ der Seele, Königsberg. Nicolovius, 1796; repr. Amsterdam, Bonset, 1966.

${ }^{2}$ Franz Joseph Gall, 'Des Herrn Dr. F. J. Gall Schreiben über seinen geendigten Prodromus über die Verrichtungen des Gehirns der Menschen und der Thiere, an Herrn Jos. Fr. von Retzer', Neuer Teutscher Merkur, 1798, 12: 311-32. In the following I will cite from: Franz Joseph Gall: Naturforscher und Anthropologe, ed. Erna Lesky, Bern, Hans Huber, 1979, pp. 47-59.

${ }^{3}$ See Max Neuburger, Die historische Entwicklung der experimentellen Gehirn- und Rückenmarksphysiologie vor Flourens, Stuttgart, Enke, 1897, p. 125; Walther Riese, 'The 150th anniversary of S. T. Soemmerring's Organ of the Soul: the reaction of his contemporaries and its significance today', Bull. Hist. Med., 1946, 20: 310-21, p. 311; Heinz Schott, 'Das Gehirn als “Organ der Seele": Anatomische und
} 


\section{Michael Hagner}

to Soemmerring more generally, one gains the impression that his concept of a circumscribed organ of the soul was the only faux pas in an admirable scientific life, during which he enjoyed a good reputation as an anatomist. ${ }^{4}$ Franz Joseph Gall, on the other hand, has often been considered as the forerunner of the localization theory of modern brain research, even if his organology was regarded as pseudo-science. ${ }^{5}$ While Soemmerring has been thought of as the end of a tradition, Gall is seen as the beginning of a new one, although it has been at the same time pointed out "that the doctrine of the seat of the soul is linked with the doctrine of cerebral localization". 6 This argument is usually based on the general assumption that brain research in the early nineteenth century took the form of a rivalry between localization theory and brain equipotentiality, according to which all functions are performed by the whole brain without any localization. ${ }^{7}$ True, Soemmerring's concept of a localized and circumscribed organ of the soul had in general no lasting influence on the further development of brain research, although from the point of view of localization theory it was preserved in Gall's theory. However, for several decades Gall was vigorously discussed by anatomists, physiologists, and philosophers, until the experimental "refutation" of his work by Pierre Flourens (1794-1864) led to his overthrow. Only from the 1860s onward was his contribution remembered by the pioneers of modern localization theory. While recognizing the heuristic value of this distinction between Soemmerring and Gall, I will attempt to follow another strategy in order to understand the development of brain research at the beginning of the nineteenth century. In analysing the contemporary reception of Soemmerring and Gall, I will show that the discussion about localizing the organ of the soul and different mental propensities and talents took place on two different levels-of philosophy and of anatomical methodology. This separation may seem trivial, but a more careful look will reveal that both levels are "part of the story of how human beings have attempted . . . to apply the categories of scientific understanding to themselves: minds and brains caught somehow between a universe of social and moral realities, and a universe that seems to stand outside of such realities, and that they choose to call

physiologische Vorstellungen im 19. Jahrhundert. Ein Überblick', Phil. Nat., 1987, 24: 3-14, p. 4; Claudio Pogliano, 'Between form and function: a new science of man', in Pietro Corsi (ed.), The mill of thought: from the art of memory to the neurosciences, Milan, Electa, 1989, pp. 144-57, on p. 147.

${ }^{4}$ Besides the authors mentioned in note 3 above, see Helmke Schierhorn, 'Samuel Thomas Soemmerring (1755-1830) als Neuroanatom', Z. mikrosk. -anat. Forsch., 1980, 94: 1051-76. A more discriminating view is expressed in the various contributions to the volume Gehirn, Nerven, Seele: Anatomie und Physiologie im Umfeld S. Th. Soemmerrings, Soemmerring-Forschungen 3, ed. Gunter Mann and Franz Dumont, Stuttgart and New York, Gustav Fischer, 1988.

5 Neuburger, for example, regarded Gall as the founder of localization theory. Cf. Max Neuburger, 'Briefe Galls an Andreas und Nannette Streicher', Sudhoffs Arch., 1916-17, 10: 3-70, p. 3. See also Erwin H. Ackerknecht and Henri Vallois, Franz Joseph Gall: inventor of phrenology and his collection, Madison, University of Wisconsin Medical School, 1956, p. 13. Other important studies on Gall are Owsei Temkin, 'Gall and the phrenological movement', Bull. Hist. Med., 1947, 21: 275-321; Erna Lesky, 'Gall und Herder', Clio Medica, 1967, 2: 85-96; idem, 'Structure and function in Gall', Bull. Hist. Med., 1970, 44: 297-314.

${ }^{6}$ Walther Riese and Ebbe C. Hoff, 'A history of the doctrine of cerebral localization: sources, anticipations, and basic reasoning', J. Hist. Med., 1950, 5: 51-71, p. 60.

7 Ibid.; Judith P. Swazey, 'Action propre and action commune: the localization of cerebral function', $J$. Hist. Biol., 1970, 3: 213-34; Edwin Clarke and L. Steven Jacyna, Nineteenth-century origins of neuroscientific concepts, Berkeley, University of California Press, 1987, pp. 241-4. 
"natural" ". If we separate philosophy and anatomical methodology, we can show that both viewpoints were part of a complex dispute about the knowledge of human nature. I will argue that Soemmerring and Gall did not agree on the first, but concurred perfectly on the second, with which I will begin.

There is no doubt that both men undertook their research within an anatomical framework. Soemmerring and Gall made far-reaching claims concerning the brain and the soul with the aid of anatomical arguments. Their basic assumption was the positive correlation between structure and function, which means that given functions were implied in given brain structures, and this led to given animal or human behaviour. More specifically, the aspect of quantity, that is the size of a defined part of the brain, was the anatomical explanation for differing behaviour. ${ }^{9}$

They were therefore criticized by anatomists, who argued against such a leading role for anatomy. The methodological question was whether or not anatomy was competent to deal with problems of localization of function and of the relationships between brain and soul. The dispute was inaugurated mainly by Karl Asmund Rudolphi (1771-1832), and, to a lesser extent, by Johann Friedrich Meckel (17811833). ${ }^{10}$ Working as professors in Berlin and Halle, both were leading protagonists in anatomy and physiology in the first decades of the nineteenth century and both saw themselves as strict advocates of empirical science. In our context, it is interesting to examine the application of this empirical belief to brain research, and we shall see that it is not useful to reduce the dispute about the brain and the soul to a strict separation between empirical evidence and hypotheses in anatomical research. This reveals an important conceptual difference between the two Prussian anatomists: Rudolphi was much more radical in his criticism and finally abandoned brain research, because his methodological scepticism was linked to a completely different context, within which he was interested in the human soul and behaviour. Meckel, on the other hand, shared methodological principles with Rudolphi, but came to conclusions that allowed him to preserve some of Gall's assumptions.

At this point the other, philosophical level of discussion becomes relevant, namely, whether or not the nature of the human soul is knowable in a physical or only in a metaphysical context. In the late eighteenth century neither Descartes' strict dualism nor La Mettrie's mechanical materialism were accepted as giving satisfactory answers to the questions concerning the presence of the soul in the brain.

Werner Krauss distinguished between two main trends that were constitutive for the discussions on human nature at that time. An "emancipatory" current understood

\footnotetext{
${ }^{8}$ Anne Harrington, 'Beyond phrenology: localization theory in the modern era', in Corsi, op. cit., note 3 above, pp. 206-14, on p. 206. Harrington focuses on the discussion from the mid-century onward, but the same is true for the earlier period.

${ }^{9}$ This problem was analysed by William F. Bynum, 'The anatomical method, natural theology, and the functions of the brain', Isis, 1973, 64: 445-68; idem, 'Varieties of Cartesian experience in early nineteenth century neurophysiology', in S. F. Spicker and H. Tristram Engelhardt, Jr. (eds), Philosophical dimensions of the neuro-medical sciences, Dordrecht and Boston, Reidel, 1976, pp. 15-33.

${ }^{10}$ Useful studies on Rudolphi's life and works are Johannes Müller, 'Gedächtnisrede auf Carl Asmund Rudolphi', in Abhandlungen der Königlichen Akademie der Wissenschaften. Aus dem Jahre 1835, Berlin 1837, pp. xviii-xxxviii; Mauritz Dittrich, 'Die Bedeutung von Karl Asmund Rudolphi (1771-1832) für die Entwicklung der Medizin und Naturwissenschaften in Berlin im 19. Jahrhundert', Wiss. Z. Univ.
} 


\section{Michael Hagner}

man as a product within the chain of being. Although this view accepted man's privileged position as the most developed and most noble being, the soul was nevertheless regarded as a variety of life. A more "theological" current, on the contrary, upheld the belief in divine creation and the immortality and indivisibility of the soul, which served to preserve the unity and the freedom of the self. ${ }^{11}$ It would be too simple to argue, however, that these two positions solely represented the often-cited querelle des anciens et des modernes. Rather, they expressed a dilemma, which became manifest in the approaches of some protagonists of Enlightenment philosophy. One example is Johann Gottfried Herder (1744-1803), who pleaded for those two positions at the same time. ${ }^{12}$ In his most influential book Ideen zur Geschichte der Philosophie der Menschheit (1784-91) he referred to the beginnings of mankind, and in comparing men and apes described the orangutan in an anthropomorphic manner. His passions and vices, Herder continued, made him similar to man, and his thinking power ("Denkungskraft") came close to reason. ${ }^{13}$ This comparison was only appropriate, because Herder accepted the relationship between anatomical and morphological development on the one hand, and the advancement of abilities on the other; the souls of men and of orangutans had their particular places within the chain of being. Thus far Herder was a protagonist of what Krauss characterized as the emancipatory current, but at the same time he insisted upon the indivisibility of the soul and pointed out that reason, memory, imagination, and passions were the various expressions of the indivisible soul. ${ }^{14}$ This account had important consequences for the discussion of the soul and the brain. While Herder regarded it as useful to examine the size of the brain in different species, he also demanded a physiological examination of the more "beautiful organization and proportion [of the brain], which enabled it to receive the mental sentiments and ideas". ${ }^{15}$ One might be inclined to assume that Herder was a Cartesian dualist. Not at all. Herder wanted to have it both ways, that is, to explain some aspects of human nature on the basis of brain research and to hold the metaphysical view of man's indivisible soul at the same time. Herder himself seemed to have no difficulties in harmonizing these two approaches. For his successors this was an enormous stimulus, but it also evoked tricky difficulties. This is clear from the different approaches of Soemmerring and Gall, who both referred to Herder in their own ways. Gall simply took the idea of the morphological development of the brain and related it to mental talents and properties by separating the mind from the soul-body problem, which for

Greifswald, math.-naturwiss. Reihe, 1967, 16: 249-77. On Meckel's biography see Rudolf Beneke, Johann Friedrich Meckel der Jüngere, Halle, Niemeyer, 1934.

${ }^{11}$ Cf. Werner Krauss, Zur Anthropologie des 18. Jahrhunderts. Die Frühgeschichte der Menschheit im Blickpunkt der Aufklärung, Ullstein Materialien 35248, Frankfurt a. M. and Berlin, Ullstein, 1987, p. 11.

12 On Herder's philosophy and anthropology see H. B. Nisbet, Herder and the philosophy and history of science, Cambridge, Modern Humanities Research Association, 1970; Manfred Wenzel, 'Die Anthropologie Johann Gottfried Herders und das klassische Humanitätsideal', in Gunter Mann and Franz Dumont (eds), Die Natur des Menschen: Probleme der Physischen Anthropologie und Rassenkunde (1750-1850), Soemmerring-Forschungen 6, Stuttgart and New York, Gustav Fischer, 1990, pp. 137-67.

${ }^{13}$ Johann Gottfried Herder, Ideen zur Philosophie der Geschichte der Menschheit, in Werke, ed. Heinrich Kurz, Leipzig, Bibliographisches Institut, 1884, vol. 3, pp. 93-4.

14 Ibid., p. 99-100.

15 Ibid., p. 98. 


\section{The soul and the brain}

him was beyond an empirical approach. Soemmerring, however, tried to fulfil Herder's ambiguous claim by explaining the presence of the soul in the brain on the basis of new anatomical and physiological insights. Soemmerring was therefore attacked for his metaphysical claims, and he was refuted for using the wrong method in this issue, while Gall was criticized for having excluded metaphysics. This position was formulated by two anatomists and physiologists, who were the main protagonists of romantische Naturphilosophie: Karl Friedrich Burdach (1776-1847) and Carl Gustav Carus (1789-1869). ${ }^{16}$ It would be too simple to propose their basic opposition to Rudolphi and Meckel on the one hand and to Soemmerring and Gall on the other. There were important differences in Burdach's and Carus's approaches. This suggests that they represented different interests despite their common philosophical attitude.

\section{SOEMMERRING AND GALL}

Although Soemmerring was aware that the question of localizing the site of interaction between soul and body was an old problem, he was convinced that he had found a completely new solution. The novel element was that he did not search for the organ of the soul in the solid matter of the brain, but in the fluid of the cerebral ventricles. To support his hypothesis he developed a theory of the function of the organ of the soul, by which he attempted to explain the process of nerve-signal transmission in the cerebrospinal fluid and the interaction between the fluid and the cranial nerves. Therefore, Soemmerring divided his argument into two: an anatomical part and a theoretical, his "transcendental physiology".

Soemmerring's basic anatomical assumption followed Descartes' claim that the meeting site of the afferent and efferent nerve signals was the place of interaction between body and soul. The next problem for Soemmerring was to identify the origins of all cranial nerves in the walls of the ventricles. Before this, however, he had to deal with anatomical questions: whether the ventricles were in fact cavities and whether they were filled with fluid. These problems had been widely discussed in the late eighteenth century. Albrecht von Haller (1708-1777) in 1762 had argued that the ventricle walls touched in living animals and that they were filled with fluid only after death. ${ }^{17}$ Soemmerring rejected both propositions by referring to his own anatomical observations. However, he did not take into account the difference, which was crucial to Haller, between the dead and living animal, thus revealing that he did not base his arguments on vivisection. ${ }^{18}$ Instead, Soemmerring saw Haller's error as a result of comparing the hollow spaces of the cerebral ventricles with those elsewhere in the body, such as the cardiac and the pleural cavities. This assumption, he argued, had led Haller to a wrong conclusion, namely that the function of the cerebrospinal fluid was

\footnotetext{
${ }^{16}$ For Burdach's life see his autobiography: Karl Friedrich Burdach, Rückblick auf mein Leben: Selbstbiographie, Leipzig, Leopold Voss, 1848; on Carus see Wolfgang Genschorek, Carl Gustav Carus. Arzt, Künstler, Naturforscher, 2nd ed., Leipzig, Hirzel, 1980.

${ }_{17}$ Albrecht von Haller, Elementa physiologicae corporis humani, vol. 4, Cerebrum, Nervi, Musculi, Lausanne, Bousquet, 1762, pp. 39-43.

${ }^{18}$ Soemmerring was harshly criticized in an anonymous review of his book for this negligence: 'Ueber Sömmerrings Entdeckungen das Organ der Seele betreffend', Journal der Erfindungen. Theorien und Widersprüche in der Natur und Arzneiwissenschaft, 1796, 5 (18): 3-55, on p. 30.
} 


\section{Michael Hagner}

only to prevent the walls sticking together. ${ }^{19}$ Soemmerring therefore suggested that a "correct" anatomical statement (that is, one not comparing the cerebral ventricles with other cavities of the body, because of their different shape and structure) leads to a "correct" physiological conclusion (that is, the fluid had a function in addition to keeping the ventricles expanded). A remarkable aspect of Soemmerring's logic is that five years earlier he had been convinced about the anatomical facts, but drew no conclusion concerning the function of the cerebrospinal fluid. ${ }^{20}$ This suggests that his interpretation of its function was not the result of anatomical evidence, but the product of his ideas about the organ of the soul.

Soemmerring also followed this strategy in his analysis of the topographical anatomy of the cranial nerves. His discussion of their origins in the brain shows that he could find them in the walls of the ventricles in only a few cases, whereas in others he could find no connections between the nerves and the ventricles. Therefore he pointed out the difficulties of dissecting, which did not allow him to find what he was looking for. ${ }^{21}$ Nevertheless he was convinced that all cranial nerves had a direct connection with the cerebrospinal fluid. For the moment he was satisfied to have found four cranial nerves to support his hypothesis. ${ }^{22}$ One of these was the olfactory nerve, for he could show a direct connection between the olfactory bulb and the lateral ventricles in mammals and in human embryos, but not in human adults. $\mathrm{He}$ explained this difference in the following way:

Does not natural history teach us that some animals are far more directed by the olfactory sense than humans? The reason is that in these animals the large cavity of the olfactory nerve accepts a large amount of the cerebrospinal fluid, and thus represents a large part of their sensorium. ${ }^{23}$

This conclusion led Soemmerring to his main anatomical argument, namely the correlation between material quantity and function. He stressed this point on several occasions, arguing that the size of the ventricles and the quantity of the fluid were the material basis for the innate differences in the development of mental talents. ${ }^{24} \mathrm{He}$ did not hesitate to bring in comparative anatomy. "I know of no animal, which possesses such large and well-formed cerebral ventricles as man." 25 This statement presents a further variation in Soemmerring's efforts to prove that man's superiority over animals had a material basis. After it was clear that the absolute size of the brain was not a valuable parameter, because the elephant and the whale had a larger brain than man, he suggested defining the weight and size of the brain in relation to the weight of the cranial nerves. ${ }^{26}$ Hence the search for the organ of the soul was dependent upon

${ }^{19}$ Soemmerring, op. cit., note 1 above, pp. 10-12.

20 Idem, Vom Baue des menschlichen Körpers, Frankfurt, Varrentrapp \& Wenner, 5 vols, 1791-96, vol. 5, pt. 1, 1791, pp. 48-9, 87.

${ }^{21}$ Idem, op. cit., note 1 above, pp. 17-18.

22 Ibid., p. 30.

23 Ibid., p. 23.

24 Ibid., p. 51.

25 Ibid., p. 52.

${ }^{26}$ For details see Paul Julius Möbius, Franz Joseph Gall, in Ausgewählte Werke, 7 vols, Leipzig, Johann Ambrosius Barth, 1903-05, vol. 7, pp. 59-63; Bynum, 'Varieties', op. cit., note 9 above, p. 29. 
the claim to demonstrate man's singularity without reconsidering Descartes' immaterial soul. Man's singularity, however, also implicated the European's superiority over the non-European for Soemmerring. This will be discussed below; but first of all the second part of Soemmerring's argument has to be analysed.

This second, and theoretical, argument concerned the interaction between the cerebrospinal fluid and the cranial nerves. The main problem was to explain the transmission of the nerve signals in fluid, and he found the solution by proposing an animation and organization for it. As this was beyond empirical evidence he introduced the dimension of "transcendental physiology", 27 which he tried to establish alongside his anatomical approach. The animation of matter and the organization of living bodies was widely discussed at that time, and, in particular, Johann Friedrich Blumenbach (1752-1840) and Immanuel Kant (1724-1804) had laid the ground for what was defined as "vital materialism". 28 Linked to Blumenbach's principle of the Bildungstrieb (formative drive), Kant had argued that one could understand the function of the individual parts of the organized body only in relation to the whole body. Therefore, the union of these parts into a whole could only happen through mutual causation, which was going beyond the domain of mechanistic thinking. At this point Kant introduced teleology, the idea that the interaction of separate parts could only be interpreted as a purposeful process. ${ }^{29}$ The problem in our context is that Soemmerring used terms like animation and organization of the body without giving credit to the theoretical background. His argument was that animation of the cerebrospinal fluid was a necessary condition for the phenomenon of life, because "the beginning of life (Urleben) or the beginning of a movement is not even thinkable in a being which is constant and unchangeable in its form" ${ }^{30} \mathrm{He}$ employed this postulate to explain the interaction between the common sensorium and the ventricular fluid, and argued that the former needed the latter for its function because of its special character. Thus Soemmerring concluded that the physiological process within the organ of the soul should also have a singular character, different from the physiological processes in the brain and nerves. It was necessary, then, to propose a qualitative change of the signal on its way from the cranial nerve to the organ of the soul, and vice versa. Therefore, the ventricular fluid was the "medium uniens". ${ }^{31}$ One might be inclined to link Soemmerring's notion of the ventricular fluid to the older concept of "animal spirits" secreted in the brain and conveyed by the nerves, but this would obscure his aims. Animal spirits had served for the transmission of sensations to the organ of the soul and to transmit messages from the latter to the different parts of the body. Soemmerring, like most contemporary anatomists and physiologists, was involved in the debate on animal electricity and the

${ }^{27}$ Soemmerring, op. cit., note 1 above, p. 37.

${ }^{28}$ Cf. Timothy Lenoir, 'Kant, Blumenbach, and vital materialism in German biology', Isis, 1980, 71: 77-108.

${ }^{29}$ Immanuel Kant: Kritik der Urteilskraft, (§ 65). in Werke, 4th ed., 10 vols, ed. Wilhelm Weischedel, Darmstadt, Wissenschaftliche Buchgesellschaft, 1975, vol. 8, pp. 483-8. For details see Lenoir, op. cit., note 23 above; idem, The strategy of life: teleology and mechanics in nineteenth-century German biology, 2nd ed., University of Chicago Press, 1989, pp. 24-30.

${ }^{30}$ Soemmerring, op. cit., note 1 above, p. 41.

${ }^{31}$ Ibid., pp. 58-60. 


\section{Michael Hagner}

nature of nerve function. ${ }^{32}$ His concept of the animation and the organization of ventricular fluids served to uphold the unity and the singularity of the soul by imposing "vital materialism" on brain research. The reverse of the coin, however, is that this reinforced an older idea of Soemmerring, which demonstrates his predilection for a "quantification" of human nature. In 1784 Soemmerring had published his treatise Über die körperliche Verschiedenheit des Mohren vom Europäer. On the basis of the dissection of three black corpses, Soemmerring not only pointed out the physical differences between black and white man, as the title had suggested; he also proclaimed that Blacks had smaller cerebral ventricles and a smaller brain ${ }^{33}$ and concluded that this might explain their "wildness, unruliness, and their minor ability to develop a higher culture". ${ }^{34}$ Soemmerring concluded from his results that within the Chain of Being Blacks were closer to apes than Whites. ${ }^{35}$ It would go beyond the scope of this paper to delve further into the late eighteenth-century anthropological discussion, but it can be argued that it was one context in which Soemmerring could use comparative anatomy, the comparison of human races, and brain anatomy and physiology in order to find a reasonable explanation for human nature and a definition for the historical standpoint of European man. "Transcendental physiology", then, could provide a philosophical support of his aims, and it moreover promised to solve the body-soul problem.

Soemmerring had a high reputation as an anatomist, but now his ambition was to reach out to not only anatomists, physiologists, or physicians, but the whole intellectual community in Germany. The reaction was enormous, but it was a complete disaster for him. Among his critics were Johann Wolfgang Goethe (1749-1832), Wilhelm von Humboldt (1767-1835), Georg Christoph Lichtenberg (1742-1799), and Blumenbach. Nobody disputed the anatomical findings, but all rejected Soemmerring's claim to link brain anatomy with metaphysics. ${ }^{36}$ The most distinguished criticism was delivered by Kant, who wrote the epilogue to the treatise of 1796, a rare example in the history of ideas where an hypothesis and its most profound criticism were published in the same book ${ }^{37}$ Soemmerring had hoped that by asking Kant to write an epilogue, Kant's authority would encourage the

${ }^{32} \mathrm{Cf}$. Werner Friedrich Kümmel, Alexander von Humboldt und Soemmerring: das galvanische Phänomen und das Problem des Lebendigen', in Gunter Mann and Franz Dumont (eds), Samuel Thomas Soemmerring und die Gelehrten der Goethezeit, Soemmerring-Forschungen 1, Stuttgart and New York, Gustav Fischer, 1985, pp. 73-87.

${ }^{33}$ Samuel Thomas Soemmerring, Über die körperliche Verschiedenheit des Mohren vom Europäer, Mainz, 1784, pp. 16-20. To be precise, he reported that Blacks had larger cranial nerves. In conformity with his earlier rule, however, by which brain size was defined relative to that of cranial nerves, Soemmerring concluded that Blacks had smaller brains.

34 Ibid., p. 24.

${ }^{35}$ For a full account of Soemmerring's anthropology cf. Georg Lilienthal, 'Samuel Thomas Soemmerring und seine Vorstellungen über Rassenunterschiede', in Mann and Dumont, op. cit., note 12 above, pp. 31-55.

${ }^{36}$ Goethe, for example, wrote in a letter (28 August 1796) that Soemmerring should have omitted the second part of the treatise dealing with transcendental physiology, and that it would have been better to leave out the soul, too. Cf. Goethe und Soemmerring. Briefwechsel 1784-1828, ed. Manfred Wenzel, Soemmerring-Forschungen 5, Stuttgart and New York, Gustav Fischer, 1988, pp. 106-7.

${ }^{37}$ For an analysis of Kant's epilogue see Riese, op. cit., note 3 above, pp. 315-17; Riese and Hoff, op. cit., note 6 above, pp. 59-61; Peter McLaughlin, 'Soemmerring und Kant: Über das Organ der Seele und den Streit der Fakultäten', in Mann and Dumont, op. cit., note 32 above, pp. 191-201. 


\section{The soul and the brain}

acceptance of his philosophical approach. His proud and grateful announcement of the epilogue, however, stands in peculiar contrast to Kant's text.

Kant suspected that Soemmerring had not differentiated sharply between the "seat of the soul" and the "seat of the organ of the soul", and asked who was competent to deal with this fundamental question. He noted a "battle of the [academic] faculties", between the medical (anatomical and physiological) on the one hand, and the philosophical on the other. ${ }^{38}$ The former, he continued, based its results on empirical reasoning, the latter demanded a priori explanations. Kant pointed out that a person taking the philosophical view in characterizing the mind or the soul could not possibly accept the anatomical and physiological concept of the seat of the soul, and vice versa. His epistemological argument was that the soul is exclusively "the object of the inner sense, and hence only determinable from temporal conditions". ${ }^{39}$ Searching for a topographical site for the soul would imply perceiving it by the same sense, that perceived the outer world.

The soul can only perceive itself through the inner sense; the body, however, can only be perceived (internally or externally) through the external senses. Hence the soul can not determine a location for itself, because in order to be able to do so it would have to make itself an object of its external Anschauung and to make itself external to itself, which is self-contradictory. ${ }^{40}$

Kant suggested a strict division of the problem: the soul itself was subject only to philosophical analysis, while physiology had the task of examining the function of the brain, or of the common sensorium, which was that part of the brain responsible for the unification of sensory perceptions. This meant, on the other hand, that Kant in principle rejected a science dealing with the soul and body at the same time.

In his second argument, Kant discussed Soemmerring's grounds for postulating the animation and organization of the cerebrospinal fluid. He refused to define a fluid as being organized, because a fluid has the property of being

a stable matter, of which each part can be moved out of its place through the smallest force, within the place, within which it is contained. This property seems to be contradictory to the concept of an organized matter, which one considers as a machine, hence as a material which is resistant to the shifting of its parts (and also to the alteration of its inner configuration) with a particular force. ${ }^{41}$

For this reason, Kant argued that the fluid was not a candidate for the organ of the soul, given that Soemmerring insisted on the concept of organization in the sense of

\footnotetext{
${ }^{38}$ Soemmerring, op. cit., note 1 above, pp. 81-2. In this context Kant's notion of the "battle of the faculties" does not have the political implications that it had for his book with the same title, published two years later: Der Streit der Fakultäten, Königsberg, Nicolovius, 1798.

${ }^{39}$ Soemmerring, op. cit., note 1 above, p. 82.

40 Ibid., p. 86: "Nun kann die Seele sich nur durch den inneren Sinn, den Körper aber (es sey inwendig oder äußerlich) nur durch äußere Sinne wahrnehmen, mithin sich selbst keinen Ort bestimmen, weil sie sich zu diesem Behuf zum Gegenstand ihrer äußeren Anschauung machen und sich außer sich selbst versetzen müßte; welches sich widerspricht."

${ }^{41}$ Ibid., p. 84: "Flüssig ist eine stetige Materie, deren jeder Theil innerhalb dem Raum, den diese einnimmt, durch die kleinste Kraft aus ihrer Stelle bewegt werden kann. Diese Eigenschaft scheint aber
} 


\section{Michael Hagner}

"vital materialism". He tried to solve this dilemma by proposing a dynamic organization of the ventricular fluid. Thus the process of signal transmission in the fluid was not mechanical-as Soemmerring had assumed-but chemical. ${ }^{42}$ With this modification Kant brought Soemmerring's hypothesis into agreement with his own definition of the organization of matter, although his attempt was not accepted by contemporary physiologists. This was because "vital materialism" was an important factor in the development of embryology and in physiology, but not in brain research, as will be seen below.

In the same context Kant also rejected "transcendental physiology". According to him, the transcendental method serves to uncover the constitutive elements of any experience. This process, however, is necessarily metaphysical, or, in Kant's words, Transzendentalphilosophie is "the system of all principles of pure reason". 43 Consequently, a physiological theory-despite its speculative character-cannot possibly be part of the transcendental method. Instead he argued that the notion of animation and organization was part of a scientific concept. As in his earlier corrective, Kant insisted on a strict separation of the scientific and the metaphysical approaches. $^{44}$

Kant's criticism was highly relevant for further discussion. Even if his position was not accepted, his precise analysis of Soemmerring's physiology and his epistemological argumentation of separating the soul and the organ of the soul created the framework for subsequent discussion. It is questionable whether Kant could have anticipated the consequences of his considerations. After all, he had not challenged the legitimacy of the concept of the organ of the soul. But he wanted to restrict it to the material site of the unification of perceptions and thus make it the subject of physiological research. With Kant's rejection of any philosophical relevance of the search for the organ of the soul by means of anatomy and physiology, the demise of this concept was in sight, and it survived only briefly, until it was replaced by two completely different concepts. The complete failure of Soemmerring's claim had consequences for the subsequent development of anatomy and physiology: either they avoided radically any philosophical viewpoint and competence; or they claimed to be philosophical in themselves. Both positions were upheld in early nineteenth-century Germany.

Franz Joseph Gall's fame began to spread long before he published an extensive study on his subject in 1810, in part with Johann Caspar Spurzheim (1776-1832). From 1800 onwards anatomists began to visit Gall in Vienna, and enthusiastic reports were published by his followers. After he and Spurzheim made a demonstration tour through Europe from 1805 to 1807 , there was hardly an

dem Begriff einer organisirten Materie zu widersprechen, welche man sich als Maschine, mithin als starre, dem Verrücken ihrer Theile (mithin auch der Änderung ihrer inneren Configuration) mit einer gewissen Kraft widerstehende Materie denkt."

42 Ibid., pp. 84-5.

${ }^{43}$ Kritik der reinen Vernunft, in Werke, op. cit., note 29 above, vol. 3, p. 64.

44 On this point cf. McLaughlin, op. cit., note 37 above, pp. 198-200. 
anatomist, or even an intellectual, who was not familiar with Gall's basic assumptions. $^{45}$

The analysis of Gall and his adversaries has focused mainly on his rejection by the Academy of Sciences in Paris under the leadership of Georges Cuvier (1769-1832) and its direct consequence, Pierre Flourens' experimental "refutation". Several historians have argued plausibly that the metaphysical basis for this attack lay in Cartesian dualism, by which the indivisibility of the soul was upheld. ${ }^{46}$ Flourens refused to accept the existence within the brain of several small brains representing different talents and propensities of the soul. His experiments led him to the conclusion that sensation, volition, and so forth were not localized in different parts of the cerebral cortex. For Flourens, this was direct proof for the unity of the self. The significant feature of Flourens' disputation is that he construed a link between a philosophical assumption and experimentation. According to him, brain localization was incompatible with the independent soul and free will, whereas equipotentiality harmonized perfectly with it. This conclusion could be possible only if anatomy or physiology were able directly or indirectly to support the Cartesian concept of the indivisible and independent soul. ${ }^{47}$

Even if Flourens was the most illustrious, he was neither the only nor the first of Gall's critics. Between 1802 and 1808, there were more than fifty publications on his doctrine, many in agreement, but many more or less critical. ${ }^{48}$ As Gall at that time had not yet published his first systematic work, the criticism was based mainly upon his lectures, his anatomical demonstrations on his tour through Germany, and the short schematic paper of 1798,49 in which he developed his research programme, and which was not superseded until the publication of his last work in 1825. Although Gall's theory has been studied intensively by various historians, ${ }^{50}$ I should like to point out some crucial arguments in the 1798 paper.

Gall's first postulate was that mental talents and propensities are innate and that they have their seat and cause in the brain. The nobility and the complexity of these functions increase in proportion to the increasing size of the brain relative to the mass of the body and in particular to the nerves. ${ }^{51}$ Gall's second point was that abilities are different from propensities, and that both are divided into several sub-groups. Thus,

${ }^{45}$ Cf. Erich Ebstein, 'Franz Joseph Gall im Kampf um seine Lehre auf Grund unbekannter Briefe an Bertuch usw. sowie im Urteile seiner Zeitgenossen', in Charles Singer and Henry E. Sigerist (eds), Essays on the history of medicine: presented to Karl Sudhoff on the occasion of his seventieth birthday November 26th 1923, London and Zurich, Oxford University Press and Seldwyla, 1924, pp. 269-322; Gunter Mann, 'Franz Joseph Galls kranioskopische Reise durch Europa (1805-1807): Fundierung und Rechtfertigung neuer Wissenschaft', Nachrichtenbl. dt. Ges. Gesch. Med., Naturwiss. Tech., 1985, 34: 86-114.

${ }^{46}$ On the metaphysical and cultural background of Flourens' criticism see Clarke and Jacyna, op. cit., note 7 above, pp. $267-85$.

47 The agreements between Gall and Flourens were pointed out by Bynum, 'Varieties', op. cit., note 9 above, pp. 27-30.

${ }^{48}$ On Gall's scientific reception in Germany see Martin Blankenburg, 'Seelengespenster. Zur deutschen Rezeption von Physiognomik und Phrenologie im 19. Jahrhundert. Versuch einer historischen Sondierung', in Mann and Dumont, op. cit., note 4 above, pp. 211-37, on pp. 215-20.

${ }^{49}$ See note 2 above.

50 Besides the authors mentioned in note 5 above see Robert M. Young, Mind, brain and adaptation in the nineteenth century: cerebral localization and its biological context from Gall to Ferrier, Oxford, Clarendon Press, 1970, pp. 9-53.

${ }^{51}$ Cited from Lesky, op. cit., note 2 above, p. 50. 
he maintained, they had their seats in different and independent parts of the brain. If this conclusion was correct, Gall argued, different forms of the brain evolved in different species; and the same was also true for individuals within one species. ${ }^{52}$ Because of the variable development of the individual organs in the brain in different individuals, their behaviour became comprehensible. Gall's last and most popular postulate was that the inner surface of the cranium is determined by the outer surface of the brain. Consequently talents and propensities could be deduced from the outer surface of the skull, if this was equivalent to the inner one. Gall's aim was to trace a causal link between the structure of the brain, its function, and human behaviour. In his paper of 1798 Gall emphasized neither the structure nor the function of the brain, but rather he postulated that function was the linking element between structure and behaviour. In 1809 he pointed out that it was natural "to consider structure and function together and to treat them as a single and identical doctrine". 53

Gall derived his research strategy from the empirical tradition of the first Vienna School. ${ }^{54}$ As a disciple of Maximilian Stoll (1742-1787), who had upheld the doctrines and methods of Boerhaave and van Swieten, Gall rejected pure reasoning and insisted upon observation. This leads to the problem of Gall's methodological approach to discovering the seats of the different organs. In this connection Gall referred mainly to anatomical and pathological observations of the brain as well as to the examination of skulls. He demanded a study of the correlation of brain lesions and clinical symptoms. Furthermore, he suggested that one should examine the specific parts of the brain by referring to the known talents and propensities of the individual, and to undertake studies in comparative anatomy. ${ }^{55}$ None of these demands was unusual around 1800 , but the point is that Gall put his hypotheses into an anatomical framework from the beginning. His strategy was not primarily anatomical, but he needed anatomy to help answer his questions. Consequently Gall was greatly interested in persuading anatomists; Rudolphi, reporting on his meeting with him in Vienna, stated that he wished to be criticized by means of anatomical arguments.

He [Gall] told me himself that if I would not be won over by his theory I should write against him, but then I should argue as an anatomist and not fight only with philosophical weapons. ${ }^{56}$

Gall's challenge to his contemporaries was that he regarded anatomy as competent to investigate problems of human nature. The consequence was that some anatomists confronted Gall with the question of how far he was able to fulfil his anatomical programme.

\footnotetext{
52 Ibid., p. 53.

${ }^{53}$ Franz Joseph Gall and Johann Caspar Spurzheim, Untersuchungen über die Anatomie des Nervensystems überhaupt, und des Gehirns insbesondere. Ein dem französischen Institut überreichtes Mémoire, Paris and Strassburg, Treuttel \& Würtz, 1809, p. 421.

${ }^{54}$ Lesky, op. cit., note 2 above, p. 155.

55 Ibid., pp. 55-6.

${ }^{56} \mathrm{Karl}$ Asmund Rudolphi, Bemerkungen aus dem Gebiet der Naturgeschichte, Medicin und Thierarzneykunde, auf einer Reise durch einen Theil von Deutschland, Holland und Frankreich gesammelt, 2
} 
Another aspect of Gall's anatomical approach leads to the question of its relationship to Naturphilosophie in Germany. Gall was perfectly aware of the provocative character of his doctrine. As early as 1798 he anticipated reproach for challenging the immortality of the soul, rejecting it with the remark that he was only interested in the "laws of the material world. ... He [the natural scientist] cannot decide about the life of the mind. He only observes, and teaches that in this life the mind is linked to the body". ${ }^{57}$ It was obvious to Gall that the assumption of several independent talents and propensities did not at all deny the eternity and the indivisibility of the soul. ${ }^{58}$ Later on, he stated more explicitly that the soul was not the object of science:

I even omit the question of the soul, although we have to think about a principle of its actions (Prinzip der Tätigkeit). As anatomists and physiologists, however, we are unable to say anything about it. ${ }^{59}$

Here, Gall seems to agree with Kant's separation of the philosophical and the physiological method. But, on the other hand, Gall did not point out clearly what he understood by a philosophical problem relevant to the knowledge of human nature. This is not surprising: for him, such a problem did not exist. In the preface to his last publication, Sur les fonctions du cerveau et sur celles de chacune de ses parties (1821-25), he made the ambition of his project quite clear.

The aim of all my investigations is to establish a doctrine of the functions of the brain.

This doctrine must lead to a complete understanding of human nature. ${ }^{60}$

If this was Gall's aim, his admission that he had not investigated the human soul becomes meaningless. He discarded metaphysical problems of the soul as irrelevant and thus proclaimed an absoluteness, which brought him into conflict with the philosophical and theological approach-a reminder of Kant's diagnosis of a battle of the faculties. In contrast to the discussion in France, which was based on the Cartesian tradition, the debate in Germany was more complex. Gall was confronted by two groups with different interests, although each focused on his anatomy and physiology of human nature. Gall was regarded in part as a pseudo-scientist or charlatan, but he was mainly criticized by established scientists because of his radicalism in terms of the accepted confines of anatomy and philosophy.

Soemmerring tried to combine anatomy with transcendental physiology, while Gall strongly rejected every kind of transcendentalism and insisted on observation. Both

\footnotetext{
vols, Berlin, Realschulbuchhandlung, 1804-5, vol. 2, p. 151. Fifteen years later Gall repeated similar statements in a letter (15 August 1820) to the anatomist Justus Christian Loder (1753-1832). See Ebstein, op. cit., note 35 above, p. 315 .

${ }_{57}$ Cited from Lesky, op. cit., note 2 above, p. 51.

58 Ibid., p. 52.

59 Gall to Andreas and Nannette Streicher, 19 October 1824. In Neuburger, op. cit., note 5 above, p. 35.

${ }^{60}$ Cited from Lesky, op. cit., note 2 above, p. 73. Although I argue that Gall was a materialist, I agree with Riese and Hoff that cerebral localization is not necessarily connected to materialism, because the former "is not concerned with the problem of the nature of this mutual relationship". Cf. Riese and Hoff, op. cit., note 6 above, p. 62.
} 


\section{Michael Hagner}

agreed in their claims to explain human nature, namely the differences between men and animals, and the variations of men one from another. On this point Gall's theory was more diversified because he introduced the categories of talents and propensities. Soemmerring sustained the philosophical importance of localization, while Gall ignored this claim. But much more importantly, both agreed with the anatomical method, and both pointed out explicitly the correlation between material size and the development of the psyche. Quantity was essential for both of them, and anatomy was their central method.

\section{RUDOLPHI AND MECKEL}

We have seen that Kant distinguished between a philosophical approach on the one hand and an anatomical one on the other. It has also been shown that Soemmerring and Gall gave concrete answers to the question of the soul and the brain. In Rudolphi and Meckel we have two anatomists who were much more reserved concerning these problems. Although they did not regard anatomy as unable in principle to deal with brain localization, they judged it incompetent at that time. At the same time, they did not relate their anatomical approach to Haller's concept of equipotentiality of brain function. It was not the case that around 1800 there was a debate between believers in Haller's concept and Gall's localization theory: the discussion had shifted to a philosophical and methodological level at which Soemmerring and Gall were cited, but not Haller. Consequently Haller played no role in Rudolphi's and Meckel's arguments. Nevertheless, their concepts were in no way identical, Rudolphi was much more involved in the controversy, and his contribution had a more constructive character.

Central to Rudolphi's criticism of Soemmerring was his conception of the use of hypotheses in science. Haller's pragmatic argument had been that hypotheses are useful in so far as they might lead to theoretical questions that could be answered by observation or experiment. Consequently, hypotheses were necessary in order to pose questions and were an important element of empirical science. ${ }^{61}$ Rudolphi, however, accepted hypotheses only in those cases where he failed to make any useful observation. His warning against uncritically mingling hypothesis and empiricism was primarily directed against the new concepts of Naturphilosophie and in particular the attempts to understand the relationship of the soul and the brain. According to Rudolphi doubt, not hypothesis or theory, should be the first step in science. ${ }^{62}$ Remarkably, Rudolphi did not refer to Haller's authority. Instead he took a position very close to that of the French Idéologues. ${ }^{63}$ The influence of this "sceptical

\footnotetext{
${ }^{61}$ Albrecht von Haller, 'Vorrede zum 1. Theile der allgemeinen Historie der Natur', in Sammlung kleiner Hallerischer Schriften, 2nd ed., 3 vols, Bern, Emmanuel Haller, 1772, vol. 1, pp. 47-77.

${ }^{62} \mathrm{Karl}$ Asmund Rudolphi, Beyträge zur Anthropologie und allgemeinen Naturgeschichte, Berlin, Haude \& Spener, 1812, pp. 41-2.

${ }^{63}$ On the Idéologues see Owsei Temkin, 'The philosophical background of Magendie's physiology', Bull. Hist. Med., 1946, 20: 10-35; George Rosen, 'The philosophy of ideology and the emergence of modern medicine in France', ibid., 328-39; Erwin H. Ackerknecht, 'Elisha Bartlett and the Philosophy of the Paris Clinical School', Bull. Hist. Med., 1950, 24: 43-60.
} 
empiricism" was much stronger in France than in Germany. ${ }^{64}$ Nevertheless, it was a motive for Rudolphi's dispute with Soemmerring. ${ }^{65}$

Rudolphi seems to have been the only anatomist who compared Soemmerring's observations of the cranial nerves with his own. He analysed each cranial nerve and did not in principle reject Soemmerring's findings, but he gave them a different interpretation. According to Rudolphi, the fact that not all the cranial nerves could be found in the walls of the ventricles detracted from Soemmerring's original hypothesis. $^{66}$ In the case of the olfactory nerve, for example, he rejected Soemmerring's postulate of a direct correlation between the size of the olfactory bulb and the sense of smell: if Soemmerring had found this anatomical structure only in human embryos, this was meaningless for function, because the function of smell in embryos was unknown. ${ }^{67}$ Rudolphi's argument was thus based on, first, a denial of the connection between structure and function, because there was as yet insufficient experimental knowledge; and second, a rejection of the optimistic "soon-to-be" strategy. He interpreted Soemmerring's and his own anatomical observations in a way which testified against a localization of the organ of the soul.

Rudolphi, of course, did not reduce the problem to the anatomy of the cranial nerves. In his discussion of Soemmerring's "transcendental physiology", he amply pointed out his scepticism. Thus he accepted the animation and organization of matter only as heuristic epithets for unknown bodily processes. For him, an acceptable definition of animation was the observable activity of those parts of the body which were able to cause an effect on themselves or on other parts of the body. But this applied to solid matter such as nerves, muscles or internal organs, and not to fluids. ${ }^{68}$ This concept seems to come close to Kant's definition of organization, but the striking difference is that Rudolphi ignored the idea of purpose, becauseaccording to him-it was an hypothesis without an empirical basis. The conclusion which Rudolphi had to draw was clear: while Kant and Blumenbach had sought a theoretical concept to explain the phenomenon of life, Rudolphi merely admitted his ignorance.

The consequence for brain function and the organ of the soul was that Rudolphi separated these two problems. He did not regard the function of the brain as undetectable in principle. However, he maintained that the contemporary methodology was insufficient, because it lacked an adequate anatomical and physiological basis. For example, he agreed with the common theoretical definition of the organ of the soul as that place in which all efferent and afferent nerves met, and whose destruction would evoke a complete loss of sensory and motor function. As no one had found such a circumscribed part of the brain, he suggested that the whole

\footnotetext{
${ }^{64}$ But the influence also existed in Germany. Cf. Erna Lesky, 'Cabanis und die Gewißheit in der Heilkunde', Gesnerus, 1954, 11: 152-82.

${ }^{65}$ For a more detailed analysis of the relationship between Rudolphi and Soemmerring see Michael Hagner, 'Soemmerring, Rudolphi und die Anatomie des Seelenorgans: "Empirischer Skeptizismus" um 1800', Medizinhist. J., 1990, 25: 211-33.

${ }^{66}$ Karl Asmund Rudolphi, Anatomisch-physiologische Abhandlungen, Berlin, Realschulbuchhandlung, 1802 , p. 181.

67 Ibid., p. 175 .

68 Ibid., p. 163.
} 


\section{Michael Hagner}

brain be regarded as the organ of the soul. ${ }^{69}$ All further speculations about the function of the brain unsubstantiated by observation and experiment were of no use to Rudolphi. Moreover, he vigorously excluded from anatomy and physiology questions concerning the soul and the nature of psycho-physical interaction. He would accept neither a dualistic nor a materialistic point of view as reasonable bases for anatomical research.

If one assumes the existence of a spiritual soul, is the assumption of a connection with an individual part of the body clearer than the assumption of a connection with a compound part? Is not the nature of a link between the soul and the body always obscure? And, on the other hand, what darkness shrouds us if we accept only material evidence. $^{70}$

Rudolphi's charge against Soemmerring, that he should have excluded questions concerning the soul, does not differ from Kant's in its consequences. There is, however, one obvious difference: Kant's was the expression of an epistemological argument, Rudolphi's the result of a sceptical interpretation of anatomical facts. I do not suggest, however, that this position, which came close to that of the French Idéologues, provided Rudolphi's only motivation. He had, of course, read Kant's epilogue, and the fact that he did not use it in his argument with Soemmerring does not exclude Kant's influence. The question is, in what respects had Kant created the general theoretical framework for an anatomist like Rudolphi, who then went on to discuss the soul and the brain in his own field. As described above, Kant had argued for a strict separation of an empirical basis for brain research, and a metaphysical viewpoint dealing with the soul. After this separation it was much easier for an anatomist to exclude the soul from anatomy. This meant, of course, a reduction of anatomical competence, but it seems to have liberated men like Rudolphi and others to delve further into what they understood by empirical research. As Rudolphi did not hold a materialistic viewpoint - and here he differed from the Idéologues - Kant's metaphysical treatment of the soul was acceptable for him. In other words: the attraction of Kant's argument for Rudolphi was that it allowed him to exclude central questions on human nature from the anatomical discourse, but then to discuss them on a completely different level. This becomes clear in Rudolphi's treatment of organology.

In contrast to his controversy with Soemmerring, Rudolphi would have agreed in principle with Gall's methodological view. Both of them were good empiricists and Gall, for example, would like Rudolphi have polemicized against Soemmerring's transcendental physiology. The controversial question, however, was, in how far it was allowable to link man's moral and physical natures. Rudolphi perfectly realized the connection between Gall's anatomy and psychology and argued against the localization of different mental talents and propensities with the remark that there was no valuable criterion for an exact definition of qualities such as pride or vanity. The reason for this, he argued, was that human behaviour was a dynamic system

${ }^{69}$ Ibid., p. 187.

70 Ibid., p. 189. 
changing during one's lifetime. Rudolphi further pointed out that our impression of human character is not necessarily identical with the character itself, because our judgement always depends on our own interests, sympathies, and antipathies. ${ }^{71} \mathrm{He}$ did not therefore reject the localization of brain function in general, but merely pointed out that it is a contradiction to establish a direct link between dynamic behaviour and a static localization in the brain, particularly since the underlying assumption-our daily experience-is anything but reliable. ${ }^{72}$ But even if it were possible to define a particular talent, this signified nothing about its representation in the brain. Provocatively, Rudolphi demanded a comparison of such a talent with a localized part of the brain in more than one case. Only then would it be legitimate to propose a correlation. It was clear to him that no one had ever been able to provide this, and therefore: "The brain has taught us nothing". 73

In Gall's theory, the innate character of mental talents and propensities was linked to the increase in size of the separate organs in the brain. Rudolphi argued that the power of an organ depended not only on its size or weight, but also on its inner energy, which was independent from these. ${ }^{74}$ In this way, the rejection of a compatibility between structure and function meant a separation between physiology and anatomy; and the size and weight of the brain were not linked to behaviour. ${ }^{75}$ In this context the brain's own physiological processes were used against Gall, although Rudolphi had earlier argued against Soemmerring that the nature of brain activity was unknown. Against both Soemmerring and Gall, Rudolphi vehemently criticized the postulation of a link between the size of the brain and human talents. It is therefore unlikely that Rudolphi's scepticism was based on purely methodological reasons alone. Another motive becomes more obvious in his attempt to make relative the innate character of mental abilities. Although he did not definitely exclude factors such as the form and energy of the brain, the ability to learn was much more important to him. The development of mental talents, he noted, mainly depended on the education of the child; and if some talents were more developed than others, this was because of the quality of education, not the innate size of any organs in the brain. ${ }^{76}$ Herewith Rudolphi brought a new dimension into the discussion. If it was Gall's aim to explain all of human nature with his system, Rudolphi suggested that this problem be discussed on a different level.

In 1800 or 1801 Rudolphi had visited not only Gall in Vienna, but also Johann Heinrich Pestalozzi (1746-1827) $)^{77}$ and his school in Burgdorf, Switzerland. Rudolphi's portrait of this visit is not only a beautiful description of life in Burgdorf,

\footnotetext{
${ }^{71}$ Rudolphi, op. cit., note 56 above, p. 164.

72 In this context Rudolphi mentioned Gall's autobiographical confession that he had known a boy with protuberant eyes and an excellent memory, which led him to assume a correspondence between linguistic talent and a facial feature. Rudolphi added that he had met several people with such eyes and a rather poor memory. See ibid., p. 166.

73 Ibid., p. 164.

74 Ibid., p. 158.

75 Rudolphi was even cautious in comparing the brains of quadrupeds and men in relation to form and function. See ibid., pp. 158-9.

76 Ibid., p. 155.

77 On Pestalozzi see Michael Heafford, Pestalozzi: his thought and its relevance today, London, Barnes \& Noble, 1967. A useful overview with extensive quotations is presented by Theodor Ballauff and Klaus
} 
it also shows his enthusiasm for the positive influence of education. ${ }^{78}$ Most fascinating for Rudolphi was that Pestalozzi's system was concerned not only with the intellectual aspect of learning, but also with the moral development and the training of the child's practical abilities: only the harmony of all three aspects guaranteed the Bildung des Menschlichen. He continued:

He [Pestalozzi] brings up boys to be human beings-the baron, future scholar or artist are not educated here; rather it is the human being who is educated. The potentialities (Anlagen) of man are developed in a general way; his strengths are drawn out from himself. ${ }^{79}$

This is an exact depiction of Pestalozzi's approach, which recognized that the task of teaching was to develop man's mind, body and heart. ${ }^{80}$

It would be too simple to argue that Rudolphi rejected Gall because he believed in man's development into an autonomous person, an active participant in an enlightened society. ${ }^{81}$ Of course, it is no coincidence that Rudolphi came to regard Gall's doctrine as a modification of Johann Caspar Lavater's (1741-1801) physiognomy, ${ }^{82}$ the only difference being that Gall characterized man on the basis of cranial bumps, not facial expressions. Rudolphi agreed with Georg Christoph Lichtenberg ${ }^{83}$ that man's character was to be described only on the basis of behaviour. ${ }^{84}$ But Gall had not denied the influence of education. Confronted with the existence of a significant bump without the correlating talent, and vice versa, Gall conceded that natural potentialities could be suppressed during a given lifetime and, conversely, that any ability could result from good education without innate talent. In this modification, however, Rudolphi saw the devaluation of the entire theory:

If there are more or less developed parts or organs of the brain which are responsible for our personalities, our likes or dislikes, and our intellectual powers, then I cannot imagine that a given talent would be completely silent if its corresponding great material potentiality (große Anlage) were present. ${ }^{85}$

Rudolphi concluded that a große Anlage did not exist in such a specific way and that it was not represented in any part of the brain. He did not accuse Gall of being an

Schaller, Pädagogik: eine Geschichte der Bildung und Erziehung, 3 vols, Freiburg and Munich, Karl Alber, 1969-73, vol. 2, Vom 16. Jahrhundert bis zum 19. Jahrhundert, 1970. pp. 480-9.

${ }^{78}$ Rudolphi, op. cit., note 56 above, pp. 137-46.

79 Ibid., p. 145.

80 Johann Heinrich Pestalozzi, Fragment über die Grundlagen der Bildung, 1803. Cited from Ballauf and Schaller, op. cit., note 77 above, p. 480.

${ }^{81}$ Rudolphi also published a volume of poetry, in which he praised the ideals of Enlightenment: Gedichte, Berlin and Greifswald, Reimer, 1798.

${ }^{82}$ Lavater's most influential work was Physiognomische Fragmente zur Beförderung der Menschenkenntnis und Menschenliebe, 4 vols, Leipzig and Winterthur, Weidmanns Erben \& Reich and Heinrich Steiner, 1775-78.

${ }^{83}$ Lichtenberg (1742-1799) had written a furious attack against Lavater: Über Physiognomik wider die Physiognomen zur Beförderung der Menschenliebe und Menschenkenntnis, Göttingen, Dieterich, 1778.

84 Rudolphi, op. cit., note 56 above, p. 183.

85 Ibid., p. 165-6. 
anti-Enlightenment fatalist, but he saw the danger of fatalistic consequences if everything in human nature were reduced to brain weight and to the specific form of some of its parts. Gall was persuaded that the effect of education was solely based on the knowledge of the organization of the brain; ${ }^{86}$ Rudolphi, on the contrary, thought that education was based on the belief in a self-aware and independent personality. ${ }^{87}$

In comparison with Rudolphi, the question of the organ of the soul and the localization of brain function is by no means as central to the work of Meckel. Its importance, however, lies in the definition of the role of anatomy. Although Meckel did not consider methodological questions, he agreed with Rudolphi's theses concerning the possibilities and the limits of anatomy. His conclusion, however, consisted of a cautious plea for the localization of brain function. Meckel had studied with Johann Christian Reil (1759-1813), Blumenbach, and Cuvier before he was appointed professor of anatomy in Halle in $1808 .{ }^{88}$ His scientific programme is revealed in his editorship of the Archiv für die Physiologie, which Reil had founded in 1796. ${ }^{89}$ After Reil's death in 1813 Meckel continued the journal as Deutsches Archiv für die Physiologie. ${ }^{90}$ In a short preface he pointed out that the journal was open only to reports of observation and experiment. It seems obvious against whom this statement was directed: from about 1805 onward Reil had made the journal available to papers dealing with animal magnetism. ${ }^{91}$ Meckel was rather critical of this controversial theory, and he made this quite plain in his preface. He rejected speculation, but disagreed also "with those who make claims for observation and experiment, although unable to complete even one experiment correctly. Their only purpose is to obtain one correct result in hundreds". 92 Meckel did not specify the rules for correct empiricism, so his strategy has to be deduced from his approach to brain anatomy. The first volume of his journal (1815) opened with a long article by Meckel on the development of the central nervous system of mammals, from which questions concerning brain localization and the organ of the soul were excluded. ${ }^{93}$ In

\footnotetext{
${ }^{86} \mathrm{Cf}$. Temkin, op. cit., note 5 above, pp. 286-8; and Pogliano, op. cit., note 3 above, p. 153.

${ }^{87}$ Rudolphi's persisting interest in pedagogy coincides with his call to the Berlin University in 1810 through the agency of Wilhelm von Humboldt. In an unpublished letter to Humboldt, Rudolphi pointed out that he was in full agreement with the so-called Bildungsprogramm; and he was quickly engaged in its practical realization. He made suggestions for the Promotionsordnung, and, more importantly, was a member of the commission drawing up the statutes for the University together with Friedrich Schleiermacher (1768-1834), Karl Friedrich von Savigny (1779-1861), and August Boeckh (1785-1867). I am preparing a more detailed study on Rudolphi's role in the building of the University and the Anatomical Institute in particular.

${ }^{88}$ There has been no general study on Meckel's contribution to anatomy and physiology. Some aspects are treated in Beneke, op. cit., note 10 above, pp. 63-117; and Lenoir, 1989, op. cit., note 29 above, pp. 56-61.

${ }^{89}$ Archiv für die Physiologie, 1795-1811, vols 1-11. From 1807 Johann Heinrich Ferdinand Autenrieth (1772-1835) was Reil's co-editor; he also edited a final volume (12) in 1815.

${ }^{90}$ Deutsches Archiv für die Physiologie, 1815-25, vols 1-11. In 1826 Meckel renamed it the Archiv für Anatomie und Physiologie, 1826-32, vols 1-7.

${ }^{91}$ Reil himself did not, however, publish on animal magnetism: his attitude to it is analysed by Heinz Schott, 'Zum Begriff des Seelenorgans bei Johann Christian Reil (1759-1813)', in Mann and Dumont, op. cit., note 4 above, pp. 183--210.

92 Deutsches Archiv für die Physiologie, 1815, 1: iv.

93 Johann Friedrich Meckel, 'Versuch einer Entwicklungsgeschichte der Centraltheile des Nervensystems in den Säugethieren', ibid., pp. 1-108.
} 


\section{Michael Hagner}

his Handbuch der menschlichen Anatomie (1815-20), ${ }^{94}$ only localization plays a rather significant role.

Concerning the organ of the soul, Meckel rejected Soemmerring's concept of the ventricles. He gave only a topographical account of the ventricles without any hint of the fluid's special character or function. ${ }^{95}$ Still more importantly, Meckel challenged the idea that the organ of the soul must be identical with the meeting-place of afferent and efferent nerves. Rudolphi had doubted the existence of such a common site, but Meckel had no firm opinion. On the one hand he left undecided with which substance the central ends of the cranial nerves were connected, and whether or not they were connected among themselves. ${ }^{96}$ At the same time, he pointed out that some sensory and motor nerves not only had a common origin, their function was in part mixed, that is, they had both motor and sensory functions ${ }^{97}$ On this basis Meckel regarded them as a unity, and he argued against Gall's opinion that systems for voluntary movement and sensory perception were represented in different parts of the brain. This leads to Meckel's judgement of Gall's localization theory. First of all he regarded Gall as a serious brain anatomist and often cited him in an approving way along with Alexander Monro secundus (1733-1817), Soemmerring, and Reil in his chapters on the nervous system. But Meckel was completely silent concerning Gall's organology, with the exception of the question of localization. Meckel's strategy in the face of difficult hypotheses was to cite arguments for and against them; the localization of mental functions was such an enigma. According to him, the problem of whether the whole brain or only circumscribed parts are the "seat of the origin (Urquell) of mental and bodily life" 98 could be decided only by observation and experiment. Hence he summed up the arguments for brain equipotentiality:

1. Even an extensive lesion of the brain does not necessarily lead to mental defects.

2. A lesion in one particular part of the brain does not necessarily lead to the loss of the same mental function in different individuals.

3. An increase in mental power is not necessarily correlated with an increase in the brain's size and weight. ${ }^{99}$

On the other hand, Meckel referred to the arguments for localization:

1. The complexity of mental activities seems to be related to the compound structure of the brain.

2. The greater development of particular mental propensities seems to parallel the development of particular parts of the brain. ${ }^{100}$

In discussing these contradictory opinions, Meckel refuted the first two arguments for equipotentiality. First, he noted, lesions of the same part of the brain were never identical in different individuals; and second, the brain's symmetrical doubleness

\footnotetext{
94 Idem, Handbuch der menschlichen Anatomie, 4 vols, Halle and Berlin, Buchhandlung des Hallischen Waisenhauses, 1815-20.

95 Ibid., vol. 3, 1819, pp. 520-35.

96 Ibid., vol. 1, 1815, pp. 288-9. Meckel-in agreement with Gall-speculated that it was the grey matter, but he did not insist upon this.

97 Ibid., p. 315.

98 Ibid., p. 327.

99 Ibid.

100 Ibid.
} 
could neutralize lesions on one side. Moreover, he argued, one area of the brain could even compensate for the loss of an area on the other side which did not correspond to it. This was also confirmed for him by the uniformity of the brain's microscopical structure (textura).$^{101}$ On the basis of these considerations alone, Meckel concluded that "different abilities of the soul (Seelenkräfte) correspond to different organs in the brain". ${ }^{102}$ This conclusion, however, does not characterize Meckel as a follower of Gall. Rather, Meckel combined several elements of the previous discussion. First of all, he argued on the basis of pathological findings. This had been an aspect of Gall's programme, but Meckel was not at all interested in explaining human nature and carefully avoided any statement about the correlation of the brain and human talents. With reference to embryology and comparative anatomy, Meckel specified the powers of the soul and localized the more primitive ones in the lower parts of the brain, and the nobler ones in the higher parts. ${ }^{103}$ The point, however, is that Meckel did not use the criterion of innate quantity to explain the differences between humans, and thus the idea of individuality was not doubted.

Rudolphi had studied the brain in order to examine the limits of anatomical and physiological research, and the investigation of the soul within an anatomical framework was, for him, beyond such limits. The consequence-and Rudolphi was aware of this-was that he accepted only the investigation of observable bodily processes. Meckel essentially agreed with him on this methodological point. But while Rudolphi rejected localization theory because of its psychological import, Meckel gave credit to the idea on a far more unpretentious level. This should not seduce us into making Meckel one of the founders of modern brain localization. His approach was far too superficial for a valuable research strategy, and the theoretical background was quite different from that of the $1850 \mathrm{~s} .{ }^{104}$ Nevertheless, Meckel's concurrence with Rudolphi in excluding questions concerning the soul from anatomical discourse shows that an important current in early nineteenth-century anatomy was willing to give up its competence in one important aspect of human nature. I argued above that Kant created the basis for this self-restriction. Moreover, Meckel could show that even Gall's idea of localization harmonized with a post-Kantian understanding of cerebral anatomy. Thus he reached a synthesis that agreed with nearly everyone.

\section{BURDACH AND CARUS}

The enormous influence of Friedrich Wilhelm Joseph Schelling's (1775-1854) writings on romantische Naturphilosophie and physiology is beyond doubt, ${ }^{105}$ and the

${ }^{101}$ Ibid., p. 328. By textura Meckel meant the smallest elements of the nerve system, the Kügelchen, which were discovered by Giovanni Maria della Torre (1713-1782).

102 Ibid., p. 328.

103 Ibid.

104 Concerning the complex problems of localization in the mid-nineteenth century see Anne Harrington, Medicine, mind, and the double brain: a study in nineteenth-century thought, Princeton University Press, 1984.

${ }^{105}$ Lenoir (op. cit., note 29 above), has doubted Schelling's influence on physiology. Lenoir focused mainly on developmental physiology, however, and a look at sensory physiology and brain physiology in general leads to a more balanced view. Lenoir's view has been criticized with some plausible arguments by Kenneth L. Caneva, 'Teleology with regrets', Ann. Sci., 1990, 47: 291-300. 


\section{Michael Hagner}

same must be true of his impact upon brain research during the Romantic period. His assumptions that were most influential in medical and physiological thinking, were (1) the philosophy of identity or totality, (2) the principle of polarity, and (3) the concept of advancement in nature. ${ }^{106}$ In particular, the idea of identity between microcosm and macrocosm, between mind and nature, brought a new element to the discussion. Schelling's equation, "nature should be Mind made visible, Mind the indivisible Nature", ${ }^{107}$ had a significance for brain research beyond that of Burdach and Carcus. ${ }^{108}$ Schelling made it quite plain that the problem of soul and body was outside the domain of empirical anatomy and physiology. He argued against the dualistic theories, which shifted the problem from one part of the brain to the other without providing any valuable solution:

But sometime, somewhere, a point must surely come where mind and matter are one, or where the great leap we have so long sought to avoid becomes inevitable; and in this all theories are alike.

Whether I allow animal spirits, electrical fluids, or types of gas to suffuse or fill the nerves, and thereby to propagate impressions from outside into the sensorium, or whether I pursue the soul into the uttermost (and still more problematical) humours of the brain (a project which at least has the merit of having done the uttermost) is, with respect to the matter in hand, altogether indifferent. It is clear that our critique has come full circle, but not that we have become in any degree wiser than we were to begin with, about that antithesis from which we started. We leave behind man, as evidently the most devious problem of all philosophy, and our critique ends here in the same extremity with which it began. ${ }^{109}$

Schelling's criticism of the attempts from Descartes to Soemmerring stressed that the missing link between brain and mind could not be found within the categories of causality. Instead he construed a unification of causation and teleology, by which nature was regarded as "a circle which returns into itself, a self-enclosed system". 110

Schelling applied his theory to brain research only in an aphoristic way and only in

\footnotetext{
106 On Schelling and Naturphilosophie see Guenter B. Risse, 'Kant, Schelling and the early search for a philosophical "science" of medicine in Germany", J. Hist. Med., 1972, 27: 145-58; Dietrich von Engelhardt, 'Romantische Naturforschung', in Historisches Bewußtsein in der Naturwissenschaft von der Aufklärung bis zum Positivismus, Freiburg and Munich, Alber, 1979, pp. 105-57. See also the various articles in Ludwig Hasler (ed.), Schelling. Seine Bedeutung für eine Philosophie der Natur und der Geschichte, Stuttgart-Bad Cannstatt, Frommann-Holzboog, 1981; Hans Jörg Sandkühler (ed.), Natur und geschichtlicher Prozeß: Studien zur Naturphilosophie F. W. J. Schellings, Frankfurt a. M., Suhrkamp, 1984; Reinhard Heckmann et al. (eds), Natur und Subjektivität: zur Auseinandersetzung mit der Naturphilosophie des jungen Schelling, Stuttgart-Bad Cannstatt, Frommann-Holzboog, 1985. For a deeper understanding of philosophical problems around 1800 it would be necessary to take into account Johann Gottlieb Fichte (1762-1814) and Georg Wilhelm Friedrich Hegel (1770-1831), although I have to neglect both of them in this essay. Important contributions in this context are Reinhard Lauth, Die transzendentale Naturlehre Fichtes nach den Prinzipien der Wissenschaftslehre, Hamburg, Meiner, 1984; Robert S. Cohen and Marx W. Wartofsky (eds), Hegel and the sciences, Dordrecht and Boston, Reidel, 1984.

${ }^{107}$ Friedrich Wilhelm Joseph Schelling, Ideas for a philosophy of nature as introduction to the study of this science, 1797. Second edition 1803, transl. Errol E. Harris and Peter Heath, Cambridge University Press, 1988 , p. 42.

108 In this context I have to neglect various naturphilosophisch concepts of Johann Joseph Doemling (1771-1803), Jakob Fidelis Ackermann (1765-1815), and Ignaz Doellinger (1770-1841).

${ }^{109}$ Schelling, op. cit., note 107 above, p. 40.

110 Ibid., p. 40.
} 
a few places. The rejection of the organ of the soul had an anti-dualist impetus, which ended in Schelling's demand that physiologists restrict their research to the investigation of animal functions. Concerning the relation of soul and body he noted: "It is not their problem how these completely opposed viewpoints will finally be united in one common entity". 111 What he meant was: carry on with your empirical investigations of the brain, we-the philosophers-will manage the interpretation of your results. This statement was certainly not a repetition or modification of Kant's position, because for Kant it was in no way the business of philosophy to interpret the results of empirical research. On the contrary, we must interpret the naturphilosophisch approach to brain theory as a challenge to Kant's epistemological separation of the soul and the brain. ${ }^{112}$ When Schelling wrote this, he could not know that only a few years later anatomists and physiologists would try to develop the synthesis he had demanded.

In his autobiography, Karl Friedrich Burdach described his visit to Franz Joseph Gall in Paris in 1826. Gall was extremely surprised:

$\mathrm{He}$ [Gall] asked me, whether I came from Königsberg and whether I was the author of the book about the brain [Vom Baue und Leben des Gehirns], and then he exclaimed: "You are visiting me?". Admittedly I had said of him in this book, whilst recognizing his other merits, that by trying to discover the basis of [psychological] phenomena he had entered an area unfamiliar to him, where his crude materialism had created an extremely daring theory. ${ }^{113}$

Gall then went to his work table and fetched Burdach's book, saying that Burdach had erroneously been convinced by Flourens' experiments (of 1824) and that he, Gall, had refuted all of them. He added that Transzendentalphilosophie was nonsense. According to this anecdote, Gall was convinced that Burdach's attack was based on the results of Flourens' experiments and upon the theory of Transzendentalphilosophie. Burdach did not reject this view in the cited passage, but Gall was wrong in both assumptions. ${ }^{114}$ Burdach was no follower of Flourens, and

${ }^{111}$ Idem, Von der Weltseele, eine Hypothese der höheren Physik zur Erklärung des allgemeinen Organismus, 1798, in Sämmtliche Werke, ed. K. F. A. Schelling, 1. Abth., 10 vols, Stuttgart and Augsburg, Cotta, $1856-61$, vol. 2, 1857, pp. 345-583, on p. 564.

112 On Schellings's opposition to Kant and its relevance for the development of Naturphilosophie see Frederick Gregory, 'Kant's influence on natural scientists in the German Romantic period', in New' trends in the history of science: proceedings of a conference held at the University of Utrecht, R. P. W. Visser et al. (eds), Amsterdam, Rodopi, 1989, pp. 53-66; idem, 'Kant, Schelling, and the administration of science in the Romantic era', Osiris, 2nd ser., 1989, 6: 17-35.

113 Burdach, op. cit., note 16 above, p. 363. On Burdach's contribution to brain research see Kurt Feremutsch, 'Organ der Seele: Beitrag zur Geschichte der romantischen Medizin nach den Werken Karl Friedrich Burdachs (1776-1847)', Mschr. Psych. Neur., 1953, 125: 371-85; idem, 'Anthropologischontologische Aspekte in Karl Friedrich Burdachs Werk "Vom Baue und Leben des Gehirns"', Schw'. med. Wschr., 1978, 108: 418-22; Alfred Meyer, 'Karl Friedrich Burdach and his place in the history of neuroanatomy', J. Neurol., Neurosurg. Psychiat., 1966, 3: 109-16.

114 There is some confusion in this passage because of the use of the word Transzendentalphilosophie. Gall was probably convinced that Burdach rejected him on the ground of Schelling's Naturphilosophie. Transzendentalphilosophie in the Kantian sense, on the other hand, is the system of all principles of pure reason (see above). A third possibility might be Kant's notion of transzendentale Naturphilosophie, the 


\section{Michael Hagner}

perhaps Gall was not aware that Burdach had already rejected his organology as early as 1810 in his book Die Physiologie. ${ }^{115}$ As noted, Gall knew Burdach's renowned Vom Baue und Leben des Gehirns, ${ }^{116}$ in which he described the anatomy and physiology of the brain on the basis of his own experiments and dissections. His theory about the presence of the soul in the brain was based mainly on the fundamentals of Naturphilosophie, and this becomes clear after comparing the 1819-26 book with that of 1810, which includes no empirical studies. Both versions agree in their philosophical claims, but differ in their application to brain physiology.

In Die Physiologie Burdach described fully his version of naturphilosophisch methodology. He distinguished between Naturkunde, which only described natural phenomena, and Naturwissenschaft, which was the philosophical knowledge of nature. Only in this way, he argued, is it possible to explain the phenomena of nature, its laws and causal connections. Physiology, then, was the doctrine of human life, inasmuch as "the organic interlocking of the original appearances of a thing constitutes life within it". 117 According to Burdach, two different methods or sources for physiology can be distinguished:

1. The empirical principle is the doctrine of organic functions. It consists of four elements: observation, experimentation, the comparison between the healthy and the diseased organism, and hypotheses. The most problematic element is experimentation, because the results of the experimenters' manipulation are often difficult to distinguish from unexpected and unintentional changes occurring in the animal. Thus, experiments must be repeated under the same conditions. Moreover, hypotheses should be based "on observation, experiments and analogy. They should be simple and not applied too closely, they should make few assumptions, and should explain a lot by the use of their postulates. Furthermore they should not contradict an accepted law of nature". 118 Thus far Burdach accepted the empirical principle, and he characterized it as the only basis of physiology in former times, and as a necessary, but insufficient basis for contemporary physiology.

2. The rational or scientific principle explains the connection between, the reason for, and the purpose of phenomena. Burdach assumed three ways of explaining these. The first was to account for them on their own. Referring to the concept of a life force and to Blumenbach's Bildungstrieb, Burdach criticized the fact that neither explained the function of the organism, but only assumed an unknown force. ${ }^{119}$ The second way was the use of analogy, which compares one group of natural phenomena with others, either from organic or inorganic nature. Here Burdach enumerated nearly all the theories around 1800 thought to explain the phenomena of life, and his criticism of them all was that there was a particular phenomenon that was not considered or even contradicted the theory. If some missing link could truly explain those phenomena, he

\footnotetext{
theory of the a priori conditions of science that is, of course, different from Schelling's concept. On this difference see the articles by Gregory, op. cit., note 112 above.

${ }_{115}$ Karl Friedrich Burdach, Die Physiologie, Leipzig, Weidmannische Buchhandlung, 1810.

116 Idem, Vom Baue und Leben des Gehirns, 3 vols, Leipzig, Dyk'sche Buchhandlung, 1819-26.

117 Idem, op. cit., note 115 above, p. 2.

118 Ibid., p. 7.

119 Ibid., p. 9.
} 
argued, then the cause of life had to be sought in an absolute principle. ${ }^{120}$ His analysis of the different modifications of materialistic and vitalistic theories attempted to show that these were useful, but could, after all, be applied only to physiological processes and functions, but not to the nature of these processes and functions. Burdach therefore proposed a third way, which explained life on the basis of the totality of nature. This was a legitimate consequence of Schelling's philosophy, because the laws for nature and mind were identical. This law-or "higher sphere" in Burdach's terminology - can be discerned in the following way: "The organization of all of nature is revealed to us by merely using reason (reine Vernunftanschauung), which is the true source of Naturwissenschaft". ${ }^{21}$ Burdach did not isolate Vernunftanschauung from the other two methods, but rather regarded it as the perfection of Naturwissenschaft. According to Burdach, science was organized like the organism itself, i.e., it was concerned with the idea of advancement. In this concept, observation and experiment played a role equal to that of the explanation of phenomena on their own or by analogy, but he accepted these methods only in reference to Vernunftanschauung, the noblest element in his model. With the construction of this model Burdach met Schelling's provocative challenge perfectly. The remarkable element in Burdach's approach is that he used it not only to explain the phenomena of life, but also to elucidate the scientific method and its historical development.

The question now is, how did Burdach apply his theory to brain research? However, his is less a synthesis of mind and matter than one of Soemmerring's and Gall's doctrines on the basis of the tenets of Naturphilosophie. Burdach defined the organ of the soul as the place where the psyche interacts with the brain. ${ }^{122}$ The gas or vapour in the cerebral ventricles, accordingly, could unify all parts of the brain, but Burdach was in no way interested in animation and organization of the ventricular fluid. With this close approximation to the dualistic view he seemed to challenge Schelling's attempt to supersede dualism. Burdach's manoeuvre to avoid conflict with Schelling was to create a polarity between the soul and the brain; in other words, the soul and the brain were merely the antagonistic aspects of one absolute principle.

Burdach's view of Gall was more ambivalent. He agreed with some aspects of organology, but attacked Gall for naivety in regarding human behaviour as dependent upon the size of a brain organ. The point of discussion was again the question of innate talents and propensities. Like Rudolphi, Burdach clearly pointed out the importance of education: "The development of the brain is most influenced by education and by the use of free will". ${ }^{123}$ But, on the other hand, Burdach accepted that organology demonstrated the main differences between man and animal. He divided the brain and the skull into eight areas and regarded the visible bumps on the skull as the representation of them. The lower areas represented the more primitive propensities, while the upper represented reason. ${ }^{124}$ The highest area revealed the combination of temper (Gemüt) and mind; here man was most distant from "physical

\footnotetext{
120 Ibid., p. 17.

121 Ibid.

122 Ibid., p. 769.

123 Ibid., p. 774

124 Ibid., p. 785.
} 


\section{Michael Hagner}

egoism" (körperlicher Egoismus) and felt "a part of the universe and hence embraces the whole universe with love". 125 The idea of the absolute, of eternity, was restricted to man. Consequently, this is "visible in the bump on the top of the skull, and this exists only in man". 126

In this way Burdach, guided by Naturphilosophie, combined elements of Soemmerring's and Gall's theories. Organology allowed him to prove the singularity of man. Burdach's criticism of Gall was not intended as a rejection of brain localization, but Gall had sinned against the naturphilosophisch tenet of combining the empirical and the rational method. Burdach argued that man's ability to recognize the absolute harmony between himself and the universe did not play the slightest role in Gall's doctrine, and this had led him to materialism. For Burdach, however, that harmony was an essential fact. It was a central aim of Naturphilosophie to supersede materialism and dualism, and Burdach fully agreed with this. In practice, however, the interpretative range of this message was wide enough to combine heterogeneous aspects. Thus Burdach was able to sustain Soemmerring's concept by stressing exhaustively the concept of polarity. The question is not so much whether his attempt was plausible or not, but rather why he made it. I propose that in 1810 Burdach had no other choice. It is obvious that Gall's organology or Rudolphi's scepticism were not reasonable alternatives for him; and equipotentiality ran counter to the hierarchy of the brain, which was so important for Burdach as a manifestation of the difference between man and animal. The concept of the organ of the soul was the final alternative, and it seemed to be a compromise for Burdach, because Soemmerring's model was not obviously dualistic.

The application of the principles of Naturphilosophie to brain research thus took place on different levels, and this led to different results. The main and constant factor was the identity between nature and soul and, as a consequence, the idea of an absolute principle. All other factors were variable. This becomes clear when Burdach's major revision of his theory in his three-volume treatise on the brain (1819-26) is considered.

In 1813 Burdach had accepted a call from the University of Königsberg to occupy the chair of anatomy and physiology. This gave him the opportunity to continue the systematic anatomical studies of the brain that he had begun in Dorpat (Tartu) in 1811 .

In the second volume of Vom Baue und Leben des Gehirns (1822) Burdach included an extensive review of the entire history of brain research up to the early nineteenth century. ${ }^{127} \mathrm{He}$ regarded Gall as highly innovative, but restricted his praise to the anatomical studies: "But Gall stepped out of his sphere of expertise by trying to discover the cause of the [mental] phenomena (Grund der Erscheinungen)". 128 Burdach ignored not only the empirical aspects of organology, but also Gall's use of

125 Ibid., p. 786.

126 Ibid., p. 787.

${ }^{127}$ Burdach, op. cit., note 116 above, vol. 2, 1822, pp. 191-243. On Burdach's role as a historian of neuroanatomy see Alfred Meyer, 'Karl Friedrich Burdach on Thomas Willis', J. neurol. Sci., 1966, 3: 109-16.

${ }_{128}$ Burdach, op. cit., note 116 above, vol. 2, 1822, p. 229. 
anatomy to legitimize his doctrine. Rather, he blamed Gall for failing to offer empirical proof for his theory, and pointed out that he had not found what he was searching for,

namely a bridge between his theory and his anatomical findings; for he could not prove that any of his so-called brain organs (with exception of the organ of the reproductive instinct, which is supposed to be the cerebellum) stands in relation exclusively with one specific part of the brain. ${ }^{129}$

This might equally well have been written by Rudolphi. Burdach also noted the incompatibility between structure and function despite Gall's and Soemmerring's attempts to reconcile them. But while Rudolphi was led to a sceptical admission of ignorance on this question, Burdach based his opinion on the basic tenet of Naturphilosophie.

In contrast to his earlier approach, Burdach then began a harsh attack on the dualistic view. He blamed Descartes for founding dualism and noted that this mechanistic explanation for the interaction between soul and body was a product of imagination, not empiricism. ${ }^{130}$ Soemmerring's anatomy was identified as the "beginning of a new era" in brain research. ${ }^{131}$ Burdach enumerated Soemmerring's anatomical discoveries and casually mentioned his doctrine of the ventricular organ of the soul without commenting on the fact that he had welcomed it only a few years before.

On the grounds of this rejection, Burdach developed a new definition of the relation between soul and brain. The soul was "a dynamic phenomenon (dynamische Erscheinung), an inner activity of life (innere Lebenstätigkeit), which had neither material form nor external movement nor spatial activity (räumliche Wirksamkeit)". ${ }^{132}$ The brain, however, had all the properties the soul lacked. From this Burdach concluded that the entire brain is the organ of the soul, and proposed an equilibrium between the two: the soul was the highest expression of the "dynamic principle" in nature just as the brain was the highest expression of the "material principle". Finally Burdach linked these principles to the dimensions of space and time: "The brain contains the same characteristics in space as the soul does in time. The brain is thus the physical image of the soul, the material condition of its appearance within finitude". ${ }^{133}$ With this Burdach abandoned his earlier assumptions: neither the differences between man and animal, nor the polarity between soul and brain played a role any more. He replaced them with a pantheistic world view, which he defined as an "apotheosis of nature". ${ }^{134}$ Despite postulating a divine order which embraced the whole universe, Burdach did not ignore the problem of the unity of the soul. Unlike the body, he noted, thinking is indivisible, impossible

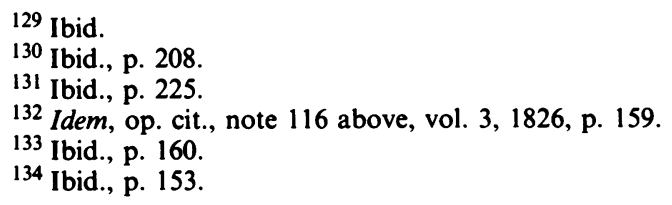




\section{Michael Hagner}

to dissect. He was in agreement with the dualistic position in accepting the value of self-consciousness and the freedom of the self. The fundamental difference between this position and the Cartesian view of Cuvier and Flourens was that Burdach did not use it to argue against the localization of mental talents and propensities. A theory of equipotential brain function would, he thought, mean ignoring the brain's high degree of complexity, and furthermore would contradict the variety of the soul's activities. ${ }^{135}$ Unlike Gall, however, Burdach combined the idea of the unity of the soul with that of a distribution in space of the various mental capabilities:

If the activity of the soul (Seelentätigkeit) is transmitted by the brain as a whole, then each individual brain structure must make its own individual contribution to it or participate in a significant way to the process as a whole. ${ }^{136}$

With this statement Burdach reached a synthesis that combined the pantheistic view of the absolute and the demand for the unity of the self with the localization of brain function. Its remarkable feature is that Burdach incorporated elements of dualism and of Gall's doctrine without involving their potential difficulties. This was only possible with naturphilosophisch presuppositions. Burdach had attempted the same course in his earlier proposition, but the result was quite different. The concepts of polarity and of the different hierarchical spheres of the brain, in particular, no longer played an important role. Of course, the superiority of ideas over physical existence was the real origin of life for Burdach, ${ }^{137}$ and human reason was the highest expression of natural action. ${ }^{138}$ His primary aim was no longer to find arguments for the superiority of the soul over matter and of man over animal. Instead he claimed that Naturwissenschaft would be identical with natural theology, if natural phenomena were regarded within the context of nature as a whole. ${ }^{139}$

What is the reason for the difference between Burdach's two propositions? Burdach conducted anatomical research at Königsberg, but it would be too simple to argue that observation and dissection evoked a shift in the application of Naturphilosophie to brain theory. It would, for example, not have been necessary for him personally to examine the brain to discover that not all cranial nerves originate in the ventricular walls: this had already been noted by Rudolphi, Gall, and Meckel. Rather it was Burdach's aim to revise some aspects of the relationship between Naturphilosophie and brain research, and he borrowed some ideas from Carus, who had been his student in Leipzig from 1807 to 1809 . According to Carus himself, this relationship was the basis for his interest in physiology. ${ }^{140}$ His main study of the brain, published

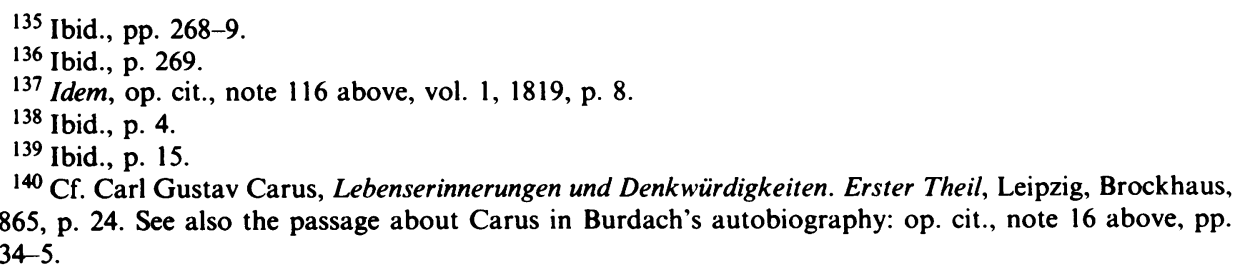


in $1814,{ }^{141}$ was an important source for Burdach's later work, ${ }^{142}$ although Carus's influence was embedded in a more general shift of Burdach's interests.

Basic to Carus's theory was the distinction between the somatic and the dynamic aspect of the nervous system, both of which he reduced to one unifying principle. Accordingly, the soul, although the highest and most noble manifestation of the nervous system, was not basically different from other phenomena of life. ${ }^{143}$ The next step would be the examination of the brain in sequence from the lowest forms to its highest expression, namely the human soul. Carus attacked his predecessors in brain research for their faulty method; that is, they began with a search for the soul. This approach, Carus argued, could only lead to the concept of the organ of the soul, whose earlier acceptance had been directed by an "incorrect understanding of ideals about the freedom of the soul, immortality, and so forth". ${ }^{44}$ Carus, far from denying the moral value of these ideals, rejected the view that they would be contradicted by the assumption of a more direct relationship between soul and brain. Because of the assumed identity of the soul and the brain Carus saw no reason to put brain research into the framework of moral questions, which would lead to the fatal mistake of trying to find the organ of the soul. His alternative suggestion was based on the well-known ideas of identity and of polarity. He thought that the conflict between different powers was responsible for all physical phenomena. The polarity between the life force (dynamic part) and the body (somatic part) leads to the expression of life, although they were identical: "the body is the spatial form of the life force; life force is the body, which appears in the form of activity". ${ }^{145}$ According to Carus, the same was true for the relationship between brain and soul. The consequence of their identity was that physical processes in the brain did not cause a change in the activity of the soul, which was the manifestation of identity in time, while the processes in the brain were its manifestation in space. ${ }^{146}$ The central point in Carus's theory was that this identity was expressed by the whole brain and the indivisible soul. This meant that the action of the brain in its totality was correlated to the idea of the self, and the product of this action was consciousness or the soul. ${ }^{147}$ At this point Carus pursued a course different from Burdach's, because on the basis of his equation of the

\footnotetext{
${ }^{141}$ Carl Gustav Carus, Versuch einer Darstellung des Nervensystems und insbesondere des Gehirns nach ihrer Bedeutung, Entwicklung und Vollendung im thierischen Organismus, Leipzig, Breitkopf \& Härtel, 1814. Carus's neuroanatomy is analysed by Kurt Feremutsch, 'Die Grundzüge der Hirnanatomie bei Carl Gustav Carus (1789-1869): ein Beitrag zur Geschichte der Medizin und Naturwissenschaften des beginnenden 19. Jahrhunderts', Centaurus, 1951-53, 2: 52-85.

142 Burdach wrote enthusiastically about Carus's work, although he admitted that he had problems with some of his ideas (see note 138 below). Cf. Burdach, op. cit., note 116 above, vol. 2, 1822, pp. 235-6. On the relation of Burdach's and Carus's brain theories see Stefano Poggi, 'Mind and brain in medical thought during the Romantic period', Hist. Phil. Life Sci., 1988, 10: suppl., 41-53. One of Poggi's main points is Burdach's influence on Carus's work Psyche, published in 1846; but he does not consider Burdach's Die Physiologie and Carus's study of the brain from 1814 and thus does not explore Carus's early influence on Burdach. Furthermore it can be argued that there exist fundamental differences between the theory of the early and the late Carus.

143 Carus, op. cit., note 141 above, p. iv.

144 Ibid., p. 5.

145 Ibid., p. 14.

146 Ibid., p. 11.

147 Ibid., p. 20.
} 


\section{Michael Hagner}

indivisibility of the soul and the totality of brain function he strongly rejected any localization of the soul or of its functions. ${ }^{148}$

Carus's refutation of Gall is thus fundamentally different from Burdach's. While the latter had accused Gall of materialism, Carus stressed that Gall's research had started with the organ of the soul, and that he had continued by seeking more inferior organs "in order to ignore no lobe or fibre of the brain which could not be regarded as the specific organ of a particular power of the soul". ${ }^{149}$ It seems peculiar that Carus should place Gall in the dualistic tradition in the search for the organ of the soul, with the difference that Gall had proposed not only one, but many organs. But Carus suspected that every theory primarily focusing on the human brain was directed by an erroneous metaphysical supposition, whereas he aimed to investigate the brain in its phylogenetic development. ${ }^{150}$ This plan, however, did not include the examination of human talents and propensities. Hence the final question in Carus's book is that of "the innate psychical propensities and talents and their manifestation in the structure (Bildung) of the brain"; 151 and he agreed with Rudolphi and Burdach that the differences between men were based on human freedom and the circumstances of life, and on education rather than on the size of the brain.

Burdach and Carus were in full agreement in regarding the soul as the temporal, and the brain as the spatial aspect of a unified principle. The reference to the dimensions of space and time had an epistemological background. In spite of its criticism of dualism and materialism, this naturphilosophisch brain theory represents an attempt to supersede Kant's epistemological separation of the soul and the brain. This does not mean that Burdach or Carus returned to the position against which Kant's criticism had been aimed. They accepted the dimensions of time and space, but they unified them on a higher level. Burdach, in particular, called attention to the insufficiency of the hypothesis that the soul was subject only to the inner senses.

Our consciousness tells us that our soul is individually confirmed to one specific body, that is, to specific spatial boundaries. We feel that this body belongs to our being and recognize that our soul is bound to it. The soul becomes manifest and operates by means of these very same spatial barriers. ${ }^{152}$

Thus individuality and personality are necessarily correlated with the body, and the knowledge of its unity with the soul is the result of self-experience. Burdach was sympathetic to the investigation of the brain on the basis of the human self, and as a result he was able to establish two levels of knowledge. The metaphysical experience of the unity of the self found its complement in physiological localization, which did not undermine the unity because it did not propose a causal connection between mind

\footnotetext{
148 Ibid., p. 50. At the same time Carus did not hesitate to localize the visual and auditory systems in the brain.

149 Ibid., p. 301.

${ }^{150}$ It is not surprising that Burdach's main criticism of Carus was directed at this point: he thought that Carus should have considered the human brain more seriously. See Burdach, op. cit., note 116 above, vol. 2, 1822, pp. 235-6.

151 Carus, op. cit., note 141 above, p. 310.

152 Burdach, op. cit., note 116 above, vol. 3, 1826, p. 153.
} 


\section{The soul and the brain}

and matter, and because it avoided assuming organs of pride, vanity, and so forth. The consequence of physiological localization, however, was Burdach's more practical orientation: in his book he presented an enormous collection of studies of patients with brain lesions, something virtually neglected by Carus. As I have argued, it is not plausible to explain the change in Burdach's approach between 1810 and 1819-26 by his experience in dissection, but it is also insufficient to explain this practical turn as solely the result of Carus's influence. Burdach was certainly not willing to give up his naturphilosophisch approach, but he had also been professor at a Prussian university since 1814. The impact of Naturphilosophie on anatomy and physiology had never been very strong in Prussia; indeed, around 1820 all Prussian anatomy professors were outspoken and vigorous critics of Naturphilosophie as vague and without any empirical value. Rudolphi and Meckel, the most famous, had a strong influence with the government of Karl Freiherr vom Stein zum Altenstein $(1770-1840) .{ }^{153}$ If Burdach did not want to lose his reputation and influence-and this included, for example, more financial support for the Anatomical Institute in Königsberg - ${ }^{154}$ then he had to ensure that his research had some empirical and practical value. In his autobiography, Burdach recounted how he sent to Altenstein an essay on morphology one day. The minister responded reproachfully that some passages might seduce the medical students to "hypotheses" and "vague raisonnement". 155 Burdach suspected that it was in fact Rudolphi who was responsible for the criticism. I do not suggest that Burdach felt compelled to convert to "empiricism", but it is reasonable to assume that the combination of a naturphilosophisch approach with a practical orientation in physiology developed along with his position as a Prussian professor. ${ }^{156}$ This might also plausibly explain the shift in the application of Naturphilosophie to brain research in Burdach's second approach, in which the unity of the self was embedded in a pantheistic view of an identity between the soul and the brain. This view, however, harmonized much better with practical demands than the former assumptions of polarity in order to sustain the organ of the soul and the hierarchical spheres of the brain. Burdach's message was clear: the concept of the organ of the soul had definitely met its demise, and Gall's doctrine was divided in a useful, empirical component and in a useless, materialistic one.

\section{THE END OF THE "ORGAN OF THE SOUL"}

My aim has been to demonstrate the complexity of the discussions on brain research in early nineteenth-century Germany. The theoretical backgrounds for the various concepts went far beyond anatomical and physiological problems. The question of the presence of the soul in the brain had been a subject of anatomy from

\footnotetext{
153 The other anatomists were Adolf Wilhelm Otto (1786-1845) in Breslau; August Franz Joseph Karl Mayer (1787-1865) in Bonn; and Friedrich Christian Rosenthal (1779-1829) in Greifswald.

${ }^{154}$ Cf. Wolfgang Bargmann, 'Zur Geschichte der Anatomie in Königsberg (Pr.) bis zum Jahre 1860', Anat. Anz., 1943, 94: 161-208.

${ }^{155}$ Burdach, op. cit., note 16 above, pp. 299-300.

156 In this context it would be interesting to examine Burdach's Die Physiologie als Erfahrungswissenschaft, 6 vols, Leipzig, L. Voss, 1826-40, in which he collaborated with younger scientists like Karl Ernst von Baer (1792-1876), Johannes Müller (1801-1858), Heinrich Rathke (1793-1860), and others.
} 


\section{Michael Hagner}

antiquity to Descartes and to Soemmerring. The latter made a final attempt to preserve the concept of the organ of the soul by combining the methods of anatomy with certain theoretical assumptions of late eighteenth-century "vital materialism". Despite his failure, the significance of the problem was appreciated. None of the authors discussed above would have denied that the relationship of the soul to the brain was a most important issue. But in the transition from the Enlightenment to the Romantic period, the epistemological view, which was stressed by Kant and picked up and transformed by Schelling and his successors, was only one component. The relation between the size, structure, and function of the human brain and behaviour was linked to the definition of the differences between men and animals, and of men among themselves. It is generally accepted that the question of whether there were innate differences between individuals or whether they were equal was a central topic of the Enlightenment; brain anatomy was not divorced from this issue. Of course, no one denied that the formula "big is beautiful"157 was an appropriate principle by which to distinguish between animal and man. Anatomists and anthropologists tried hard to find an effective parameter for correlating brain and species within the Chain of Being. This general agreement, however, must not be transferred to the problem of characterizing men. ${ }^{158}$ Here we can discern the element common to scientists like Soemmerring and Gall. For both the formula "big is beautiful" was connected with the explanation of human nature. Although Gall was much more radical than Soemmerring, anatomy was absolutely necessary to both. This materialistic view was rejected with several arguments. Rudolphi stressed the methodological standpoint and argued that anatomy was not suitable to support that view. At the same time, he was in full agreement with Burdach and Carus that human behaviour was primarily a result of education and of the circumstances of life. This coalition suggests that the distinction between Naturphilosophie and empiricism is not necessarily useful. If Gall's pessimism denied the progressive perfection of mankind, then the Enlightened ideal of the equality of man united scientists who had quite opposite theories. ${ }^{159}$

Focusing on the problem of the unity and indivisibility of the soul, we see another puzzling interrelation of the different opinions. The independence of the soul was a central assumption in French dualism (Cuvier, Flourens) and in German Naturphilosophie (Burdach, Carus). The difference seems to be that Kant's epistemological definitions stimulated further discussions in Germany, but not in France. Kant's definition forced the Naturphilosophen to consider and to accept the logical premises for distinguishing between space and time. Strictly anti-dualistic and anti-materialistic thinkers, they proposed that the brain and the soul were only two aspects of one and the same thing, namely the absolute principle. This tenet not only led to different applications in Burdach's and Carus's approaches, but also within Burdach's own work. This suggests that Naturphilosophie was a spiritus rector

157 I have borrowed the term from Bynum, 'Varieties', op. cit., note 9 above, p. 29.

158 The relation of human nature and anthropology is the subject of Mann and Dumont, op. cit., note 12 above. See also Pogliano, op. cit., note 3 above.

${ }^{159}$ On Gall's fatalism see Temkin, op. cit., note 5 above, pp. 300-7. 
without absolute authority, and with a field wide enough to allow for various attempts at new orientations. ${ }^{160}$

Finally, the discussion around 1800 cannot be subsumed as the choice between localization theory and brain equipotentiality. For Burdach, the first was not the alternative to the second. Instead he combined both on the basis of Naturphilosophie and proposed two different points of view regarding the same thing. His basic aim was to avoid materialism. Meckel, on the other hand, came to a similar pragmatic conclusion by reducing the problem to anatomical and clinical observation. Nevertheless, it is true that Burdach and Meckel favoured cerebral localization, whereas Rudolphi and Carus did not. But all the physiologists examined here were influenced by Gall, and each used a completely different strategy in order to reach their conclusions. Rudolphi rejected cerebral localization on the grounds of scepticism of the validity of anatomical observations and of his psychological premises; Carus on naturphilosophisch grounds. Again, we could place Rudolphi and Carus in the category of anti-localizationists, although they had radically different positions.

Soemmerring's and Gall's concepts were discussed within various dimensions and finally rejected by a variety of arguments. This "plurality" was at least an expression of the scientific, philosophical, and political situation in early nineteenth century Germany. It demonstrates the enormousness of the theoretical enterprise required to create a methodology for explaining the phenomena of life. The soul and the brain were the most sensitive entities in this field, because understanding them not only meant understanding the world but also the self, including human thoughts and feelings.

${ }^{160}$ I completely agree with Brigitte Lohff, who argues that in general naturphilosophisch physiology should be seen as a search for a new basic methodology in science, and as such was a necessary precursor of biophysical physiology: Die Suche nach der Wissenschaftlichkeit der Physiologie in der kit der Zomantik: ein Beitrag zur Erkenntnisphilosophie der Medizin, Stuttgart and New York, Gustav Fischer, 1990. 